\title{
Empirical and modelled energy performance in Kuwaiti villas: understanding the social and physical factors that influence energy use
}

\author{
Badria Jaffar ${ }^{1}$, Tadj Oreszczyn, Rokia Raslan \\ UCL Energy Institute, 14 Upper Woburn Place, London, WC1H ONN, England, United Kingdom
}

\begin{abstract}
This paper investigates the physical and social determinants of energy use in four case study villas in Kuwait. The investigation consisted of a 12 month mixed-method longitudinal monitoring and surveying study followed by building energy modelling. Monitoring and surveying provided empirical data about household energy use, internal temperatures, building and system characteristics and occupant energy-use behaviours. This data was used to ground models to better predict energy use. Models grounded with empirical data show that space cooling accounts for $50 \%$ to $75 \%$ of total energy use in villas. Results suggest that drivers of cooling energy are varied, with $30 \%$ of cooling energy in some villas attributable to heat gains from appliances. Furthermore, while the study found no distinct reduction in measured and modelled annual energy use intensities of villas with improved levels of efficiency (insulation and double glazing), such measures did contribute to more uniform internal temperatures. The study also identified key occupant energy-consuming behaviours including a tendency not to adjust air conditioning (AC) thermostat settings during periods of summer travel and lack of regular AC maintenance. The approach and findings of the study can inform future studies in Kuwait seeking to understand energy use in a nationally representative sample.
\end{abstract}

Keywords: Longitudinal monitoring and surveying; empirical data; building energy modelling; occupant behaviour; Kuwait case study

\footnotetext{
${ }^{1}$ Corresponding author.

Tel: +44 $7900104555,+96590010989$

Email address: b.Jaffar@ucl.ac.uk, b_jaffar@hotmail.com
} 


\section{Introduction}

In Kuwait almost $60 \%$ of the national electrical power generated is consumed by residential buildings [1]. Rising residential demand is increasingly undermining the country's hydrocarbon export capacity and posing significant energy security challenges for the Kuwaiti government [2, 3]. In its most recent National Development plan the government announced its intention to build 45,000 new housing units, largely in the form of single family villas, by 2020 [4]. While such plans are necessary to meet housing demands of a rapidly growing population, they will require substantial electricity production, especially as existing installed capacity $(14,702 \mathrm{MW})$ is relatively close to peak summer demand (11,220 MW) [1]. Despite this, very little research and data is available about household energy use in Kuwait and the key determinants that influence this [5].

Traditionally, energy demand research and the energy efficiency challenge have, on an international level, been defined in technical terms and studies have largely focused on a building physics approach examining the thermal performance of materials and the efficiency of heating and cooling systems [6, 7]. Energy models have increasingly been used as tools to aid the design and evaluation of policies aimed at reducing building energy use [8-10]. Energy models however, are reliant, to varying degrees, on simplifications and assumptions that significantly impact their predictive power and output results $[8,9]$. In particular, models commonly assume standard occupant behaviour, overlooking the interaction between people and technology [8]. Consequently, research has continuously shown a discrepancy between modelled and measured building energy use, with a limited understanding of the underlying reasons [11-13]. Recently, interest in the sociotechnical nature of energy has increased, with researchers seeking to collect and integrate data about both the social and physical elements of buildings to better understand energy use and the impact of energy efficient technologies in order to effectively inform policy interventions [14-16].

This study investigates both the social and physical factors that drive household energy use in Kuwaiti villas. It focuses on villas as they are the main housing type for Kuwaiti nationals and constitute the bulk of previous and future government housing projects [17]. The study adopts a multiple case study approach, examining the energy performance of four villas through longitudinal monitoring and surveying followed by the development of building energy models grounded in empirical data. Empirical monitored energy and internal temperature data is combined with surveys of occupant behaviours, building systems, building form and fabric, and used to support the development of more valid models for understanding energy use. The intention of the study was not to generalise beyond the sample of households, but for the approach and findings to act as a platform to inform further research, in particular future studies that seek to understand the energy use in a nationally representative sample. The study has made two important contributions to the residential energy demand research field in Kuwait:

1. It represents a novel attempt to collect longitudinal empirical data about the physical and social characteristics of villas in their natural setting (including their energy use), of which there is very little available data.

2. It demonstrates the value of integrating physical and social empirical data in the creation of more representative energy models to better inform policy interventions.

Throughout the paper, the term 'energy' is used to refer to metered energy (i.e. electricity). This is because energy use for cooling, heating, lighting, appliances and hot water in Kuwaiti villas is in the form of electricity. For cooking, while many properties use gas (in the form of butane/propane $12 \mathrm{Kg}$ cylinders), electric ovens and stoves are also commonly used [5]. 


\section{Literature review}

\subsection{Residential energy consumption in Kuwait}

Kuwait relies extensively on its abundant oil resources both as a source of national income and to meet its entire electric power generation requirements $[2,3]$. In the past the country's high resource per capita has allowed it to export most of its hydrocarbon production, however rapidly rising residential electricity consumption is increasingly straining the country's export capacity and presenting complex energy security challenges [2,3].

High residential energy demand has been triggered by a number of factors. These include the government's generous welfare and energy subsidy program, a rapid growth in the population (with an average annual growth rate of 3.1\% [4]), progressive increases in dwelling sizes (due to building regulation changes by Kuwait Municipality), and harsh summer climatic conditions (with maximum temperatures reaching higher than $50^{\circ} \mathrm{C}$ ) [2,3,]. The energy subsidy programme, whereby residential consumers pay less than $5 \%$ of the market value of electricity (a rate of KD $0.002 / \mathrm{kWh}$ of the electricity generation cost of KD $0.047 / \mathrm{kWh}$ - equivalent to $\$ 0.01$ and $\$ 0.16$ respectively at the time of writing) has led to unconstrained energy practices and an intrinsic demand for large centrally air-conditioned homes [3].

In an attempt to improve building energy efficiency and reduce the rate of electricity demand, the Kuwait Ministry of Electricity and Water (MEW) has, since 1983, enforced a mandatory Energy Conservation Code applicable to all new and renovated buildings [18]. This code, updated in 2010 and again in 2014, was developed by the Kuwait Institute for Scientific Research (KISR), and stipulates minimum thermal insulation requirements for walls, roof, columns and glazing as well as peak power guidelines for air-conditioning units [18]. While researchers at KISR estimate that a building constructed in full compliance with the 1983 code requires $40 \%$ less cooling [19], in practice, little evidence of the code's impact exists [3,19].

The energy performance of residential villas in Kuwait and their energy efficiency potential has been examined by a number of researchers [20-30]. A recent study by Ameer and Krarti [20] develops a base case energy model for a prototypical Kuwaiti villa and undertakes a series of analyses to determine the impact of energy efficiency measures, while considering the country's high subsidized energy prices. Al Ragom [22] also uses energy modelling to develop various retrofitting cases that represent potential retrofitting scenarios, concluding that substantial energy savings can be achieved at the national level even when implementation costs are supported by the government. A number of researchers have collected empirical data about Kuwaiti villas and their occupants, although published studies [5,23,24] are few and limited. A study by Al-Mumin et al. [23] for example, provides valuable occupancy, appliance and lighting use data collected from a sample of 30 villas, but does not measure energy use or describe physical features of surveyed villas. Similarly, a field study by Alajmi and Loveday [24] collected useful information about indoor environmental conditions and occupants' thermal comfort, but provides no energy, building or occupant behaviour data.

While there have been many important studies about the performance of residential villas in Kuwait, there remains a lack of robust empirical data about the Kuwaiti housing stock and its energy use which also describes the building physical form, appliances, services and occupancy. 


\subsection{The evolving nature of residential energy demand research}

Since the oil price adjustments of the 1970s, residential energy demand researchers worldwide have sought to better understand the sector's energy use profile and the determinants that influence this. Studies have traditionally focused on a building physics approach, examining factors such as building size, age, thermal performance and system efficiency, excluding the influence of people $[6,7]$. Building energy models have largely been used as tools in such studies and in the design and evaluation of policies aimed at reducing building energy use [8-10]. Such models consist of the computerized simulation of a building to quantitatively assess its energy performance [9], and are reliant on simplifications and assumptions that can considerably influence their output results [8]. Consequently, studies have increasingly found discrepancies between modelled and measured building energy use, often with a limited understanding of the reasons for this [12-14].

In recent years, there has been a shift in research towards human centered aspects of energy with studies seeking to better understand the impact of occupants on energy use $[23,31$ 37].This has largely been in the form of examining the impact of occupant socio-demographic characteristics and/or occupant behaviour [23,31-37]. Socio-demographic characteristics commonly examined include household income, household size, household age, and household education level [32-34]. Studies exploring the impact of occupant behaviour have largely been addressed in terms of occupant preferences for space heating/cooling (including thermostat set points and number of rooms heated/cooled)[23, 31, 35], window opening behaviour [36] and presence at home [23,36]. While researchers highlight the important impact of occupant behaviour, the magnitude of this remains relatively unclear $[33,34,37]$. This, in part, is due to the challenges associated with measuring behaviour which, in effect, is driven by several underlying factors that include the thermal quality of a building, the type and performance of its technical systems, outdoor climate, energy tariffs, occupant age and income [34-37].

More recently, researchers have shown increased interest in an integrated approach to the study of building energy performance and in particular the socio-technical nature of energy consumption [14-16]. Studies are progressively recognizing the importance of investigating energy use 'in context' and of collecting and combining empirical data about both the social and physical elements of buildings to better understand energy performance [14-16]. Detailed empirical data about buildings and their occupants, although often costly and time-consuming to collect, can allow for the development of more representative energy models to better inform policy interventions in this field [6-8,38]. 


\section{Methodology}

This study adopts a multiple case study approach investigating the energy performance of four case study villas through two methods: 1) longitudinal monitoring and surveying and 2) building energy modelling grounded with empirical data.

\section{$3.1 \underline{\mathrm{A} \text { brief overview of sample villas }}$}

Villas have been selected using a maximum variation purposive sampling strategy, which entails the recruitment of a diverse sample based on pre-defined criteria [39]. For this study the rationale was to increase sample diversity in terms of building age (a proxy for fabric efficiency), building size (total built up area), villa type (private or government built villa), household size (number of occupants and family structure) and household income, in order to assess the impact of such factors on driving energy use. While the objective was to examine different types of villas, care was also taken to ensure all fell within the norm (of typical villas in Kuwait) in terms of general form and fabric, building services, and household size $[5,23]$. Four villas were recruited from a sample of 250 villas that formed part of a larger cross-sectional quantitative household survey undertaken by the authors of this paper [5].

Table 1 presents the main features of each villa, which ranged from older (pre-1983 code) uninsulated and single glazed buildings to newer (post-1983 code) insulated and double glazed buildings. All villas are constructed from a reinforced concrete skeleton of beams and columns with non-load bearing concrete walls. Household occupants varied from a retired couple to larger families with young and/or adult children. As is common in Kuwait, all villas are centrally cooled throughout, via a number of packaged direct expansion air conditioning (AC) units with air cooled condensers. Each packaged unit (located outdoors on the rooftop) serves a number of rooms and is controlled by a single thermostat (located in only one of the rooms being cooled). Split units, which work on a room by room basis, are primarily used in staff bedrooms and the main external kitchen. During winter $\mathrm{AC}$ units were not used for heating in any of the villas, despite some having a heating setting. 
Table 1 - Main characteristics of case study villas

\begin{tabular}{|c|c|c|c|c|}
\hline & Villa 1 & Villa 2 & Villa 3 & Villa 4 \\
\hline $\begin{array}{l}\text { Occupant } \\
\text { description }\end{array}$ & $\begin{array}{l}\text { Middle aged working } \\
\text { couple with four } \\
\text { children aged between } \\
\text { 8-16 years, two female } \\
\text { staff, } \\
\text { one male driver }\end{array}$ & $\begin{array}{l}\text { Retired couple with } \\
\text { one working adult son, } \\
\text { two female staff and } \\
\text { one male driver }\end{array}$ & $\begin{array}{c}\text { Young couple } \\
\text { (working husband and } \\
\text { housewife) } \\
\text { with three children } \\
\text { aged } 6 \text { months- } 7 \\
\text { years, and two female } \\
\text { staff }\end{array}$ & $\begin{array}{l}\text { Middle aged working } \\
\text { couple with two } \\
\text { teenage children, an } \\
\text { aunt, an elderly } \\
\text { grandmother, two } \\
\text { female staff, one } \\
\text { nurse, and three male } \\
\text { staff. }\end{array}$ \\
\hline $\begin{array}{l}\text { Number of } \\
\text { occupants }\end{array}$ & 9 & 6 & 7 & 12 \\
\hline $\begin{array}{c}\text { Year of } \\
\text { construction }\end{array}$ & 1982 & 1981 & 2010 & 1999 \\
\hline Villa type & Government & Private & Private & Private \\
\hline Tenure & $\begin{array}{c}\text { Bought by existing } \\
\text { homeowners in } 2011\end{array}$ & $\begin{array}{l}\text { Built and owned by } \\
\text { existing homeowners }\end{array}$ & $\begin{array}{l}\text { Built and owned by } \\
\text { existing homeowners }\end{array}$ & $\begin{array}{l}\text { Bought as a new build } \\
\text { in } 2000\end{array}$ \\
\hline $\begin{array}{l}\text { Internal floor } \\
\text { area }\left(\mathrm{m}^{2}\right)\end{array}$ & 397 & 568 & 705 & 809 \\
\hline $\begin{array}{c}\text { Number of } \\
\text { floors }\end{array}$ & 2 & 2 & 3 & $\begin{array}{c}4 \text { (on of which is a } \\
\text { basement) }\end{array}$ \\
\hline $\begin{array}{c}\text { Household } \\
\text { income } \\
\text { (monthly) }\end{array}$ & $\begin{array}{c}2300 \mathrm{KWD} \\
(\$ 7611)\end{array}$ & $\begin{array}{c}2700 \mathrm{KWD} \\
(\$ 8934)\end{array}$ & $\begin{array}{c}1500 \text { KWD } \\
(\$ 4963)\end{array}$ & $\begin{array}{c}3000 \text { KWD } \\
(\$ 9926)\end{array}$ \\
\hline $\begin{array}{l}\text { Air-conditioning } \\
\text { system }\end{array}$ & $\begin{array}{c}2 \text { central units } \\
\text { (1 to cool each floor) } \\
\text { Each unit controlled by } \\
1 \text { digital thermostat } \\
1 \text { split unit } \\
\text { (in staff bedroom) }\end{array}$ & $\begin{array}{c}4 \text { central units } \\
\text { (2 to cool each floor) } \\
\text { Each unit controlled by } \\
1 \text { analogue thermostat } \\
7 \text { split units } \\
\text { (in staff bedrooms and } \\
\text { in newer built } \\
\text { extensions of villa) }\end{array}$ & $\begin{array}{l}5 \text { central units } \\
\text { ( } 2 \text { to cool the ground } \\
\text { and first floors \& } 1 \text { to } \\
\text { cool the second floor) } \\
\text { Each unit controlled by } \\
1 \text { digital thermostat } \\
3 \text { split units } \\
\text { (in staff bedroom and } \\
\text { main external kitchen) }\end{array}$ & $\begin{array}{c}5 \text { central units } \\
\text { ( } 2 \text { to cool the ground } \\
\text { and first floors } \& 1 \text { to } \\
\text { cool the basement) } \\
\text { Each unit controlled by } \\
1 \text { analogue thermostat } \\
6 \text { split units } \\
\text { (in staff bedrooms, } \\
\text { ironing room, and main } \\
\text { kitchen) }\end{array}$ \\
\hline $\begin{array}{c}\text { Villa } \\
\text { renovations/ } \\
\text { extensions }\end{array}$ & $\begin{array}{c}\text { New central AC } \\
\text { packaged units } \\
\text { installed in } 2013 \text { to } \\
\text { recent } 2010 \mathrm{MEW} \text { code } \\
\text { standards }\end{array}$ & $\begin{array}{l}\text { Ground floor family } \\
\text { living room, bedroom } \\
\text { 3, external kitchen, } \\
\text { dining room and staff } \\
\text { bedrooms were built as } \\
\text { later extensions in the } \\
\text { mid } 1990 \text { 's to pre } 1983 \\
\text { code standards. }\end{array}$ & None & None \\
\hline
\end{tabular}

Note: conversions to US dollars based on rates as of June 6, 2018 (1KWD=\$3.31) 


\subsection{Longitudinal monitoring and surveying}

The aim of the longitudinal study was to examine occupant behaviors, household energy use and internal temperatures, as well as building form, fabric and system characteristics. This lasted for a total of 12 months to account for seasonal and climatic effects throughout the year. A review of historic utility bills (covering the period between 2011-2014), floor plans, and construction drawings was undertaken prior to the start of monitoring and surveying to obtain basic factual information about each villa. A mixed method approach for data collection and analysis was used to allow for the corroboration and validation of findings (figure 1). This included:

- Energy use and indoor temperature monitoring - weekly electricity meter readings were undertaken and internal temperatures monitored every 20 seconds, in rooms that made up at least $95 \%$ of the volume of the building. Between 15 and 20 Onset HOBO data loggers (model type: U12-012, accuracy: $\pm 0.35^{\circ} \mathrm{C}$ [40]) were used per villa (one or two per room). External temperature was also monitored by placing three hobos outdoors, on the roof, in a Stevenson screen (an enclosure to shield from dust, wind and rain).

- Physical survey of building fabric and services - this consisted of a walk-through survey, following the first occupant interview, to inspect and photograph building elements such as walls, windows, number and type of lights, the location and settings of controls, number and type of appliances, AC system power ratings, and hot water tanks. At the same time as the survey, homeowners were asked about specific on-site devices and how they were used.

- Social survey of building occupants - this consisted of two types of qualitative occupant interviews: 1) first occupant interview, prior to the start of monitoring, and 2) a series of follow-up interviews throughout the monitoring period. The first occupant interview aimed to gather information about household's socio-economic background, building and system characteristics, and occupant behaviours. Follow-up interviews aimed to understand occupants' role in driving energy use and assist in the analysis of monitored temperature data. Follow-up interviews consisted of probing questions about occupant use and engagement with the building's technical systems and appliances, routines, and any changes that may have occurred. All interviews were semi-structured, lasted about one hour and were conducted in the occupants' homes. In designing interview schedules a number of similar studies that have used qualitative interviews to determine the effect of occupant behaviour were reviewed $[14,41]$. All interviews were recorded and transcribed to facilitate analysis.

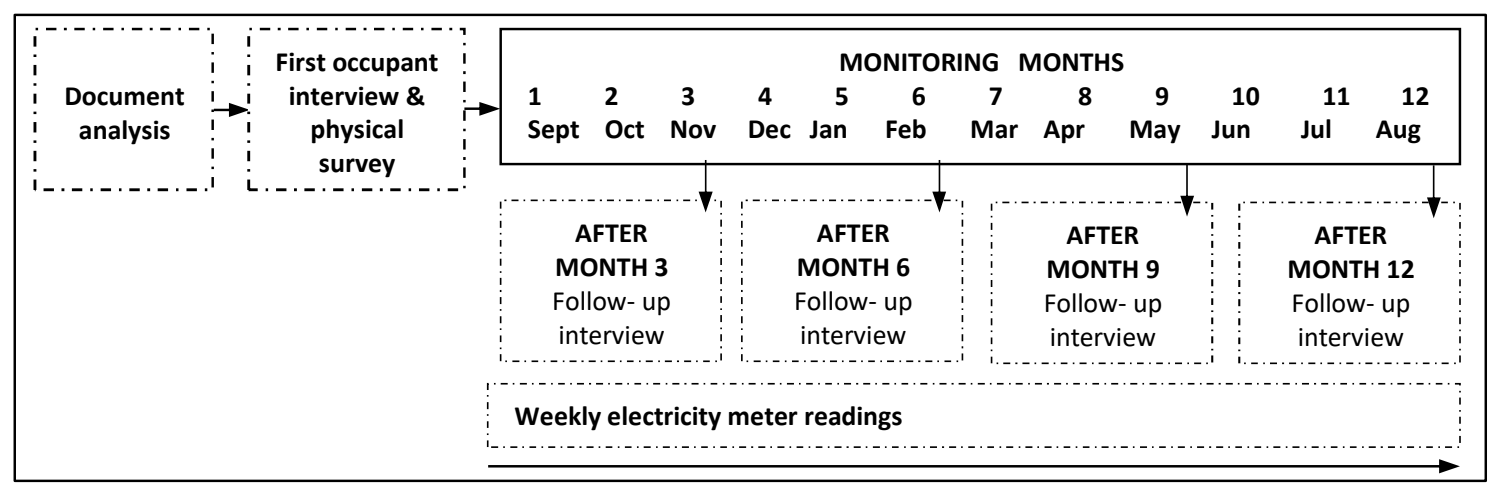

Figure 1 - Monitoring data collection framework 


\subsection{Energy modelling}

The aim of energy modelling was to provide quantifications and insights into key determinants of energy use and their relative importance in each villa. Multi-zonal models were developed for each villa using the software program Simergy (version 2.5.1) [42]. Simergy is a building energy modelling program that incorporates detailed information about building systems, internal loads and schedules, building site and climate. It is an interface to Energy Plus, an energy simulation engine, validated by the US department of Energy, generating annual, monthly or hourly energy demand for a building based on specific weather files [43].

To reduce assumptions and uncertainties, modelling was informed by physical and social data collected during the monitoring and surveying process. Real weather data (during the year of monitoring) was also used in simulations including air temperature, relative humidity, and solar radiation retrieved from Kuwait International Airport weather station [44]. All model runs presented in this paper include shading from adjacent buildings. Table 2 and 3 describe model input parameters, and table 4 illustrates different visualizations of simulated villas.

Once models were appropriately grounded in the monitored and surveyed data, and shown to reasonably simulate villas they represent, a differential sensitivity analysis was undertaken to quantitatively assess the importance of various factors on energy use. This involved the variation of one input in each simulation to determine its direct impact on an output value (while other inputs remained at their base values) [45].

\subsubsection{Model development and calibration}

To facilitate model development, the following modelling strategy was followed for all villas:

1. Developing a library in Simergy with appropriate construction, internal load and HVAC templates.

2. Generating building geometry (by drawing over actual architectural DWG drawings).

3. Assigning appropriate construction templates for each villa, and defining individual custom windows, external doors, and surrounding internal walls.

4. Creating thermal zones based on a consideration of the function of the space, the method used to condition the space, its position relative to the exterior, and the measured data available. Such considerations are based on guidelines suggested by Raftery et al [46] .

5. Assigning appropriate internal load templates and schedules to different thermal zones.

6. Creating zone HVAC groups and assigning appropriate HVAC templates to each.

7. Model calibration. The purpose of model calibration is to explore discrepancies between model prediction and measured building performance and determine if such discrepancies can be accounted for by reviewing model input assumptions. [47]. While many approaches to model calibration have been suggested, ranging from manual to automated (a thorough review of calibration approaches is available from Coakley, et al. [47]), there remains no consensus on a formal calibration methodology or process $[46,47]$. Broadly, statistical indices are used as international reference criteria for validating calibrated models as defined by ASHREA Guideline 14 [48], the International Performance measurement and Verification Protocol (IPMVP)[49] and the Federal Energy Management Program (FEMP) 
[50]. Criteria indicate how well modelled energy consumption matches measured energy data at a selected time interval (hourly or monthly) [47]. In this study three main calibration steps were undertaken:

i. Baseline modeling following a defined strategy for model development (outlined in steps 1-6 above) and using real physical and social data collected during the monitoring and surveying study as well as real weather data.

ii. Running simulations and comparing modelled and measured energy data both annually and monthly, as well as modelled and measured internal temperature data to detect major variations. This process consisted of checking and fixing any model input errors and further refining operation schedules.

iii. Model validation using standard statistical criteria defined by [48-50] for the mean bias error (MBE) and the coefficient of variations of the root mean squared error (CV (RMSE)): this involved calculating the MBE and CV(RMSE) for each villa. The MBE is a measure of how closely simulated data corresponds to monitored data and is calculated as shown in equation 1. CV(RMSE) is a measure of the variability between measured and simulated data and is useful for capturing situations where errors are self-cancelling. $\mathrm{CV}(\mathrm{RMSE})$ is calculated as shown in equation 2. For this study, as metered energy consumption was recorded at a weekly basis for each villa, monthly, rather than hourly, criteria are applied.

$$
\operatorname{MBE}(\%)=\frac{\sum_{i=1}^{N p}\left(m_{i}-s_{i}\right)}{\sum_{i=1}^{N p}\left(m_{i}\right)}
$$

Where $m_{i}$ and si are the measured and simulated data points for each model instance ' $i$ ' and $N_{p}$ is the number of data points at interval ' $p$ ' ( $\left.N_{\text {monthly }}=12\right)$.

$$
\operatorname{CV} \operatorname{RMSE}(\%)=\frac{\sqrt{\sum_{i=1}^{N p}\left(m_{i}-s_{i}\right)^{2} / N_{p}}}{\bar{m}}
$$

Where $m i$ and si are the measured and simulated data points for each model instance ' $\mathrm{i}$ ' and $N_{p}$ is the number of data points at interval ' $p$ ' ( $\left.N_{\text {monthly }}=12\right)$, and $\bar{m}$ is the average of the measured data points. 
Table 2 - An overview of the input variables included in the modelling exercise and their source

\begin{tabular}{|c|c|c|}
\hline General inputs & Description & Source \\
\hline Location & Kuwait & $\mathrm{N} / \mathrm{A}$ \\
\hline $\begin{array}{l}\text { Simulation } \\
\text { weather file }\end{array}$ & $\begin{array}{l}\text { Custom weather file covering the period } \\
\text { from } 2015 \text { to } 2016 \text { based on data retrieved } \\
\text { from Kuwait International Airport } 405820\end{array}$ & [44] \\
\hline $\begin{array}{l}\text { Modelling } \\
\text { software }\end{array}$ & Simergy version 2.5 .1 & {$[42]$} \\
\hline $\begin{array}{l}\text { Fabric efficiency } \\
\text { and infiltration }\end{array}$ & $\begin{array}{l}\text { Wall, roof, window } U \text {-values, thickness, and } \\
\text { building infiltration }\end{array}$ & $\begin{array}{l}\text { Construction details based on physical observation are } \\
\text { provided in table } 3 \text {. For older villas ( } 1 \text { and } 2 \text { ) fabric } U \text {-values } \\
\text { were based on those noted in published residential energy } \\
\text { simulations for villas of similar age in Kuwait [20-28]. } \\
\text { For newer villas ( } 3 \text { and } 4 \text { ) fabric U-values were based on } \\
\text { requirements from the MEW } 1983 \text { energy code [18] }\end{array}$ \\
\hline Space cooling & $\begin{array}{l}\text { Number of central and split AC units, } \\
\text { thermostat set points, period of operation } \\
\text { and coefficient of performances (COP). In } \\
\text { Simergy COP is the ratio of the gross total } \\
\text { cooling capacity to electrical power inputs } \\
\text { (in watts) of the DX cooling coil unit at } \\
\text { rated conditions. }\end{array}$ & $\begin{array}{l}\text { Number of } A C \text { units, thermostat set points and period of } \\
\text { operation are based on physical and social survey data (table } \\
1 \text { and } 7) \text {. The input value representative of COP at the average } \\
\text { external temperature }\left(35 C^{\circ}\right) \text { in each model was assumed } \\
\text { based on system age and } M E W \text { code requirements (1983 and } \\
\text { 2010) [18]. }\end{array}$ \\
\hline Space heating & Portable electric heaters & $\begin{array}{l}\text { Heating (incorporated as part of winter plug load schedules) } \\
\text { was based on physical and social survey data }\end{array}$ \\
\hline Occupancy & $\begin{array}{l}\text { Number of occupants and occupancy } \\
\text { schedules }\end{array}$ & $\begin{array}{l}\text { Number of occupants and occupancy schedules were based } \\
\text { on social survey data (figure 7) }\end{array}$ \\
\hline Plug loads & $\begin{array}{l}\text { Number of electrical appliance and usage } \\
\text { schedule }\end{array}$ & $\begin{array}{l}\text { Plug load intensity }\left(\mathrm{W} / \mathrm{m}^{2}\right) \text { and usage schedules were based } \\
\text { on physical and social survey data (table } 8 \text { and figure } 7) .\end{array}$ \\
\hline Lighting & $\begin{array}{c}\text { Number and wattage of lighting fixture and } \\
\text { usage schedule }\end{array}$ & $\begin{array}{l}\text { Lighting load intensity }\left(\mathrm{W} / \mathrm{m}^{2}\right) \text { and usage schedules were } \\
\text { based on physical and social survey data (table } 7 \text { and figure } 7) \text {. }\end{array}$ \\
\hline
\end{tabular}

Table 3 - Main building and occupancy simulation parameters

\begin{tabular}{|c|c|c|c|c|}
\hline & Villa 1 & Villa 2 & Villa 3 & Villa 4 \\
\hline External wall construction & $\begin{array}{c}100 \mathrm{~mm} \text { brick, } 15 \mathrm{~mm} \\
\text { cement mortar, } \\
120 \mathrm{~mm} \text { concrete } \\
\text { block, } 15 \mathrm{~mm} \text { cement } \\
\text { plaster finish } \\
\text { (no insulation) }\end{array}$ & $\begin{array}{c}\text { 40mm stone, } 15 \mathrm{~mm} \\
\text { cement mortar, } \\
150 \mathrm{~mm} \text { concrete } \\
\text { block, } 15 \mathrm{~mm} \text { cement } \\
\text { plaster finish } \\
\text { (no insulation) }\end{array}$ & $\begin{array}{c}20 \mathrm{~mm} \text { cement plaster, } \\
180 \mathrm{~mm} \text { autoclaved } \\
\text { aerated concrete with } \\
\text { inbuilt insulation, } 15 \\
\text { mm cement plaster } \\
\text { finish }\end{array}$ & $\begin{array}{c}40 \mathrm{~mm} \text { stone, } 15 \mathrm{~mm} \\
\text { cement mortar, } 40 \mathrm{~mm} \\
\text { insulation, } 150 \mathrm{~mm} \\
\text { concrete block, } 15 \mathrm{~mm} \\
\text { cement plaster finish }\end{array}$ \\
\hline $\begin{array}{c}\text { External wall U-value } \\
\left(\mathrm{W} / \mathrm{m}^{2} .^{\circ} \mathrm{K}\right)\end{array}$ & 2.31 & 2.31 & 0.57 & 0.57 \\
\hline Roof construction & $\begin{array}{l}20 \mathrm{~mm} \text { tiles, } 15 \mathrm{~mm} \\
\text { cement mortar, } \\
20 \mathrm{~mm} \text { sand screed, } \\
150 \mathrm{~mm} \text { concrete } \\
\text { block, gypsum board } \\
\text { (no insulation) }\end{array}$ & $\begin{array}{l}20 \mathrm{~mm} \text { Tiles, } 15 \mathrm{~mm} \\
\text { cement mortar, } \\
20 \mathrm{~mm} \text { sand screed, } \\
150 \mathrm{~mm} \text { concrete } \\
\text { block, gypsum board } \\
\text { (no insulation) }\end{array}$ & $\begin{array}{c}20 \mathrm{~mm} \text { Tiles, } 15 \mathrm{~mm} \\
\text { cement mortar, } 20 \mathrm{~mm} \\
\text { sand screed, } 40 \mathrm{~mm} \\
\text { insulation, } 150 \mathrm{~mm} \\
\text { concrete block gypsum } \\
\text { board }\end{array}$ & $\begin{array}{c}20 \mathrm{~mm} \text { Tiles, } 15 \mathrm{~mm} \\
\text { cement mortar, } 20 \mathrm{~mm} \\
\text { sand screed, } 40 \mathrm{~mm} \\
\text { insulation, } 150 \mathrm{~mm} \\
\text { concrete block, } \\
\text { gypsum board }\end{array}$ \\
\hline Roof U-value (W/m². $\left.{ }^{\circ} \mathrm{K}\right)$ & 0.69 & 0.69 & 0.39 & 0.39 \\
\hline Glazing type & $\begin{array}{l}6 \mathrm{~mm} \text { single pane } \\
\text { tinted glazing with } \\
\text { aluminium frames }\end{array}$ & $\begin{array}{l}6 \mathrm{~mm} \text { single pane } \\
\text { tinted glazing with } \\
\text { aluminium frames }\end{array}$ & $\begin{array}{l}6 \mathrm{~mm} \text { double tinted } \\
\text { reflective glazing with } \\
\text { aluminium frames }\end{array}$ & $\begin{array}{l}6 \mathrm{~mm} \text { double tinted } \\
\text { glazing with } \\
\text { aluminium frames }\end{array}$ \\
\hline Glazing U-value $\left(\mathrm{W} / \mathrm{m}^{2} .^{\circ} \mathrm{K}\right)$ & 6.41 & 6.41 & 3.33 & 3.61 \\
\hline Glazing ratio (\%) & 4.3 & 8.2 & 5.9 & 3.27 \\
\hline Infiltration (ACH) & 0.8 & 0.8 & 0.4 & 0.5 \\
\hline Cooling (COP) & 2.4 & 1.7 & 2.4 & 2.0 \\
\hline Occupancy $\left(\mathrm{Occ} / \mathrm{m}^{2}\right)$ & 0.02 & 0.01 & 0.01 & 0.01 \\
\hline Lighting $\left(\mathrm{W} / \mathrm{m}^{2}\right)$ & 4.5 & 5.4 & 5.7 & 9.8 \\
\hline Plug load $\left(\mathrm{W} / \mathrm{m}^{2}\right)$ & 29.1 & 9.5 & 16.4 & 22.3 \\
\hline $\begin{array}{c}\text { Annual average fabric heat } \\
\text { gains (W) }\end{array}$ & 3063 & 6164 & 3850 & 5852 \\
\hline $\begin{array}{c}\text { Annual average total heat } \\
\text { gains (W) }\end{array}$ & 10030 & 12284 & 10306 & 15480 \\
\hline $\begin{array}{c}\text { Annual average heat gain } \\
\text { parameter }\left(\mathrm{W} / \mathrm{m}^{2}\right)\end{array}$ & 26 & 22 & 15 & 19 \\
\hline
\end{tabular}


Table 4 - Visualization of simulated villas

\begin{tabular}{|l|c|c|}
\hline Villa 1 & Visualisation of front of villa & Visualisation of villa with adjacent buildings \\
\hline Villa 2 & South & \\
\hline Villa 4 & & \\
\hline
\end{tabular}




\section{$\underline{\text { Results }}$}

\subsection{Monitoring results}

\subsubsection{Measured energy consumption and indoor temperature}

Annual energy (electricity) consumption comprises the annual cooling, heating, lighting, appliance, hot water and auxiliary energy used to drive HVAC system performance. Table 5 and figure 2 present the annual and seasonal metered energy consumption of each villa (measured in kWh), normalised by floor area and number of occupants. Although villas with larger internal floor areas (villas 3 and 4) had higher annual energy use (kWh/annum), annual energy use intensities ( $\mathrm{kWh} / \mathrm{m} 2 / a n n u m)$ in villas with more occupants (villas 1 and 4 ) were higher. The influence of cooling is shown by the highest energy use occurring during the summer season. Occupancy based energy use (kWh/m2/occupant) however, was highest in villas with more occupants (villa 1 and 4) during the winter and lowest in these villas during the summer. This suggests that other factors, in addition to AC cooling, are important in driving energy use in these villas including occupancy, hot water and appliance use. This also suggests that the method of central space conditioning may be somewhat overshadowing the impact of household size (number of occupants) on energy use; in summer villas are centrally cooled throughout (including many unused rooms and regardless of the number of occupants), while during winter heating (via portable electric heaters) is used intermittently in some occupied rooms only. In particular, Villa 1 , had more stable energy use $\left(\mathrm{kWh} / \mathrm{m}^{2}\right)$ throughout the year; relatively higher in winter and lower in summer compared to the other villas. Some explanations for such consumption were partly sought during occupant interviews, which indicated that villa 1 occupants spent much more time at home during winter, using many appliances throughout the day including kitchen appliances, mobile and tablet chargers, TVs, as well as electrical lighting. Similarly, relatively lower summer energy use is, to some extent, due to villa 1 homeowners increasing thermostat settings by $1^{\circ} \mathrm{C}$ for one month during a family holiday in July (unlike in other households where no thermostat adjustments were made during summer travel).

Table 5 -Seasonal and total yearly metered energy consumption in the different villas throughout the monitoring period (September 2015-August 2016)

\begin{tabular}{|c|c|c|c|c|c|c|c|c|}
\hline & \multicolumn{2}{|c|}{ Villa1 } & \multicolumn{2}{|c|}{ Villa2 } & \multicolumn{2}{|c|}{ Villa3 } & \multicolumn{2}{|c|}{ Villa4 } \\
\hline $\begin{array}{l}\text { Measured annual } \\
\text { energy use (kWh) }\end{array}$ & \multicolumn{2}{|c|}{86,943} & \multicolumn{2}{|c|}{97,128} & \multicolumn{2}{|c|}{122,670} & \multicolumn{2}{|c|}{182,025} \\
\hline Internal floor area $\left(\mathrm{m}^{2}\right)$ & \multicolumn{2}{|c|}{397} & \multicolumn{2}{|c|}{568} & \multicolumn{2}{|c|}{705} & \multicolumn{2}{|c|}{809} \\
\hline \multirow[t]{3}{*}{ Number of occupants } & \multicolumn{2}{|c|}{9} & \multicolumn{2}{|c|}{6} & \multicolumn{2}{|c|}{7} & \multicolumn{2}{|c|}{12} \\
\hline & \multicolumn{2}{|c|}{ Villa1 } & \multicolumn{2}{|c|}{ Villa2 } & \multicolumn{2}{|c|}{ Villa3 } & \multicolumn{2}{|c|}{ Villa4 } \\
\hline & $\mathrm{kWh} / \mathrm{m}^{2}$ & $\begin{array}{l}\mathrm{kWh} / \mathrm{m}^{2} / \\
\text { occupant }\end{array}$ & $\mathrm{kWh} / \mathrm{m}^{2}$ & $\begin{array}{l}\mathrm{kWh} / \mathrm{m}^{2} / \\
\text { occupant }\end{array}$ & $\mathrm{kWh} / \mathrm{m}^{2}$ & $\begin{array}{l}\mathrm{kWh} / \mathrm{m}^{2} / \\
\text { occupant }\end{array}$ & $\mathrm{kWh} / \mathrm{m}^{2}$ & $\begin{array}{l}\mathrm{kWh} / \mathrm{m}^{2} / \\
\text { occupant }\end{array}$ \\
\hline Annual energy use & 219 & 24 & 171 & 29 & 174 & 25 & 225 & 19 \\
\hline Autumn (Sept-Nov) & 52 & 5.7 & 31 & 5.2 & 43 & 6.1 & 51 & 4.3 \\
\hline Winter (Dec-Feb) & 47 & 5.2 & 13 & 2.2 & 16 & 2.3 & 35 & 2.9 \\
\hline Spring (Mar-May) & 54 & 6.0 & 34 & 5.7 & 38 & 5.4 & 52 & 4.3 \\
\hline Summer (Jun-Aug) & 62 & 6.9 & 81 & 14 & 73 & 10 & 81 & 6.8 \\
\hline
\end{tabular}

Note: In all villas the central AC was switched off at the end of November and switched back on at the start of March 


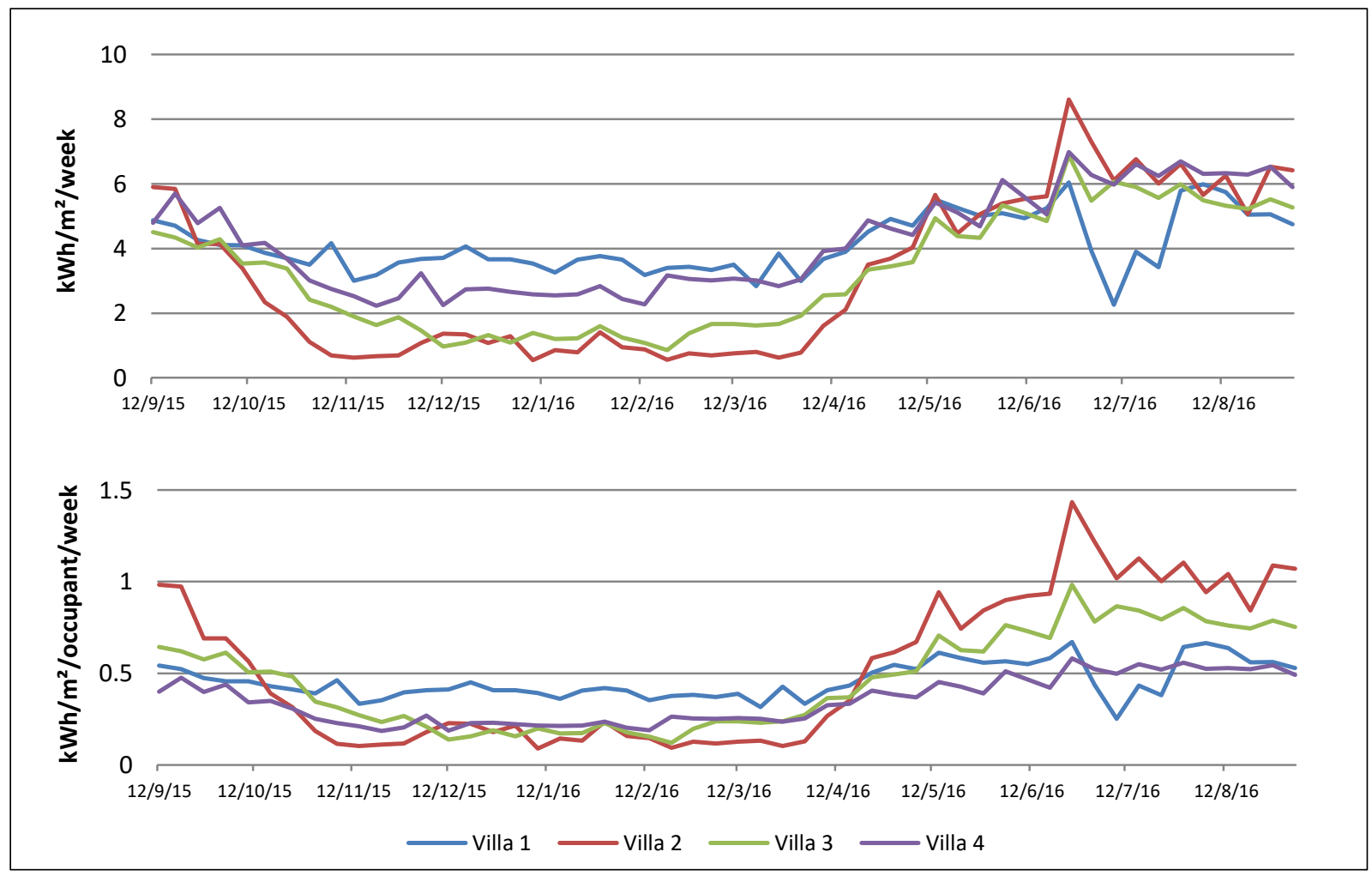

Figure 2 - Variation in weekly metered energy consumption in the different villas

The combination of other strands of data including internal temperature enabled further determination of the impact of different energy use drivers. Figure 3 illustrates the average volume weighted internal temperatures of each villa throughout the year indicating when the AC was switched ON and OFF. This includes all measured internal and external temperature data including when occupants were away on vacation. In general, when the AC was switched ON (during summer, spring and autumn), internal temperatures remained relatively stable in all villas despite wide differences between external and internal temperatures. Villa 2's internal temperature had a higher degree of variability than other villas possibly due to its older inefficient central AC units and greater number of split unit, more likely to be used intermittently than central cooling. In villa 1 , increased variability observed specifically during higher external temperatures is due to homeowners increasing central $\mathrm{AC}$ thermostats by $1^{\circ} \mathrm{C}$ for one month during a family vacation in July and reducing them back down in August. Internal temperatures in the older uninsulated and single glazed villas (1 and 2) were also found to be higher than in the newer insulated and double glazed villas ( 3 and 4 ) when the AC was switched ON. This, which in part is due to homeowners in older villas using higher thermostat set points (as indicated in table 7 further below), may also be due to increased heat gains into the building through infiltration and the fabric. In contrast, during winter, when the AC was switched off, newer villas had higher internal temperatures than older villas, which again could be due to electric heating and incidental heat gains (occupancy, solar, appliance gains) being retained more effectively within the building fabric. 


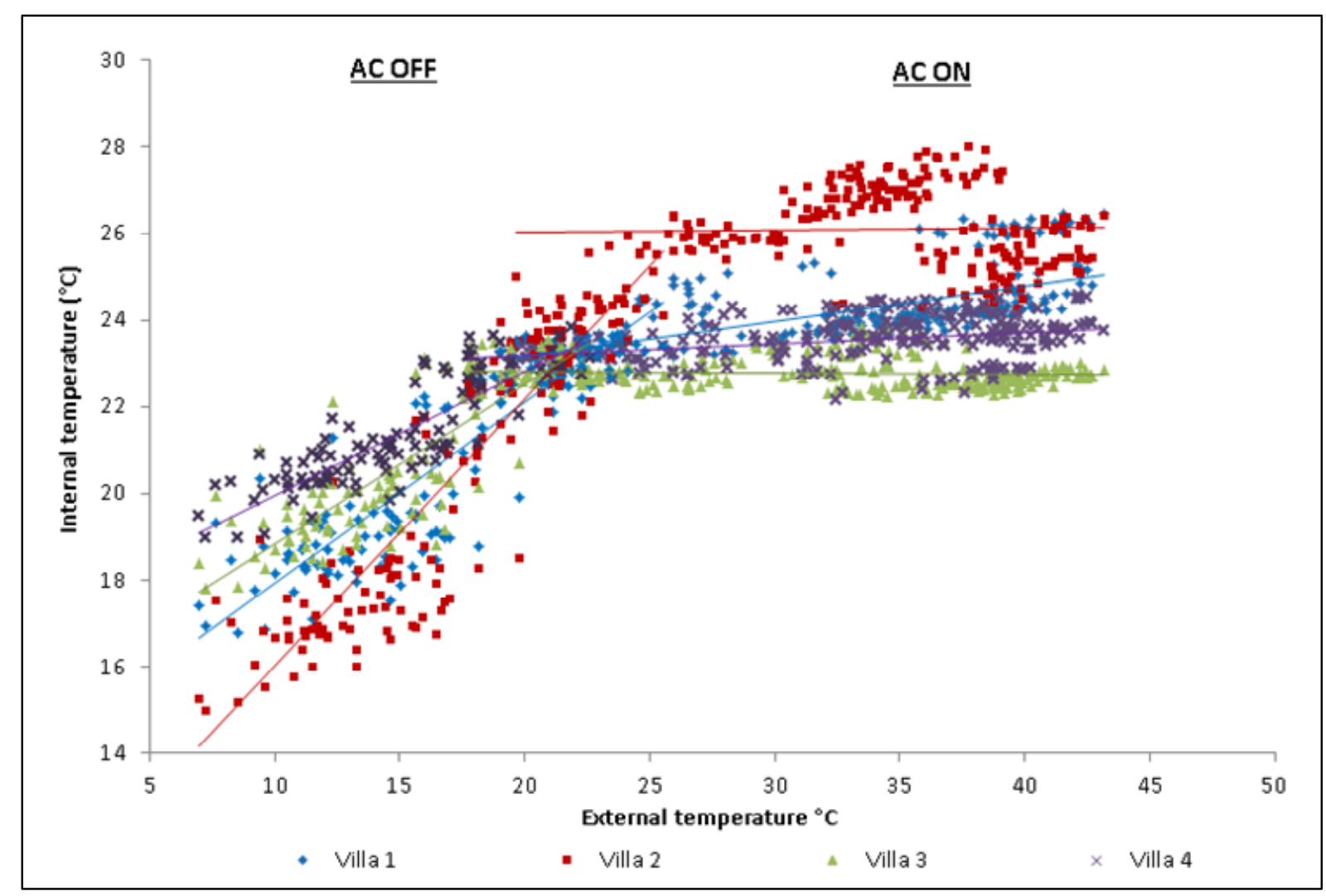

Figure 3 - Daily average volume weighted internal temperatures vs. external temperature thorough the entire monitoring period, indicating when the $A C$ is switched ON and OFF

Figure 4 shows the variation of average summer and winter internal temperatures of individual rooms. Bedrooms (with exception to staff bedrooms and bedroom 2 in villa 4), were relatively cooler during summer and warmer during winter. In the 9 months follow up interview and physical survey it was noted that homeowners in villa 4 set the thermostat in bedroom 2 (which simultaneously controls cooling in bedroom 2 and the main kitchen) to higher settings $\left(25.5^{\circ} \mathrm{C}\right)$, as the room is used by an elderly, bed-ridden occupant who requires and prefers warmer temperatures. This also led villa 4 homeowners to install two split units in the main kitchen to provide additional cooling in that space. Similarly, all staff bedrooms were relatively warmer during summer as they are intermittently cooled by split units and are close to sources of heat gain i.e. washing machine/ironing facilities. During winter, bedrooms were generally warmer as electric heaters were used more in these spaces. Furthermore, comparing room temperatures during summer and winter, greater fluctuations were noticed between rooms in villas 2 and 4 . In villa 2 this is potentially due to many split units used throughout the newer extensions, while in villa 4 fluctuations between rooms can be attributed to a diverse occupant age group with different requirements for thermal comfort (middle aged homeowners and teenager children prefer cooler temperatures in their first floor bedrooms and living space, while an elderly occupant prefers warmer temperatures in the ground floor).

To indicate the degree of variation within rooms, figure 5 presents the standard deviations of temperature during summer and winter. In all villas, internal temperatures in rooms (with exception to staff bedrooms and bedroom 3 in villa 2 coold by split units) were more stable during summer when the central $A C$ was swtiched on, than during winter, as indicated by higher standard deviation values of approximelty $1.5^{\circ} \mathrm{C}$ to $2^{\circ} \mathrm{C}$. Most rooms in newer (post-code) villas also had lower standard 
deviations of temperature compared to rooms in older (pre-code) villas during both summer and winter, suggesting that measures such as fabric insulation and double glazing are likely to be contributing to more unifrom internal temperatures.

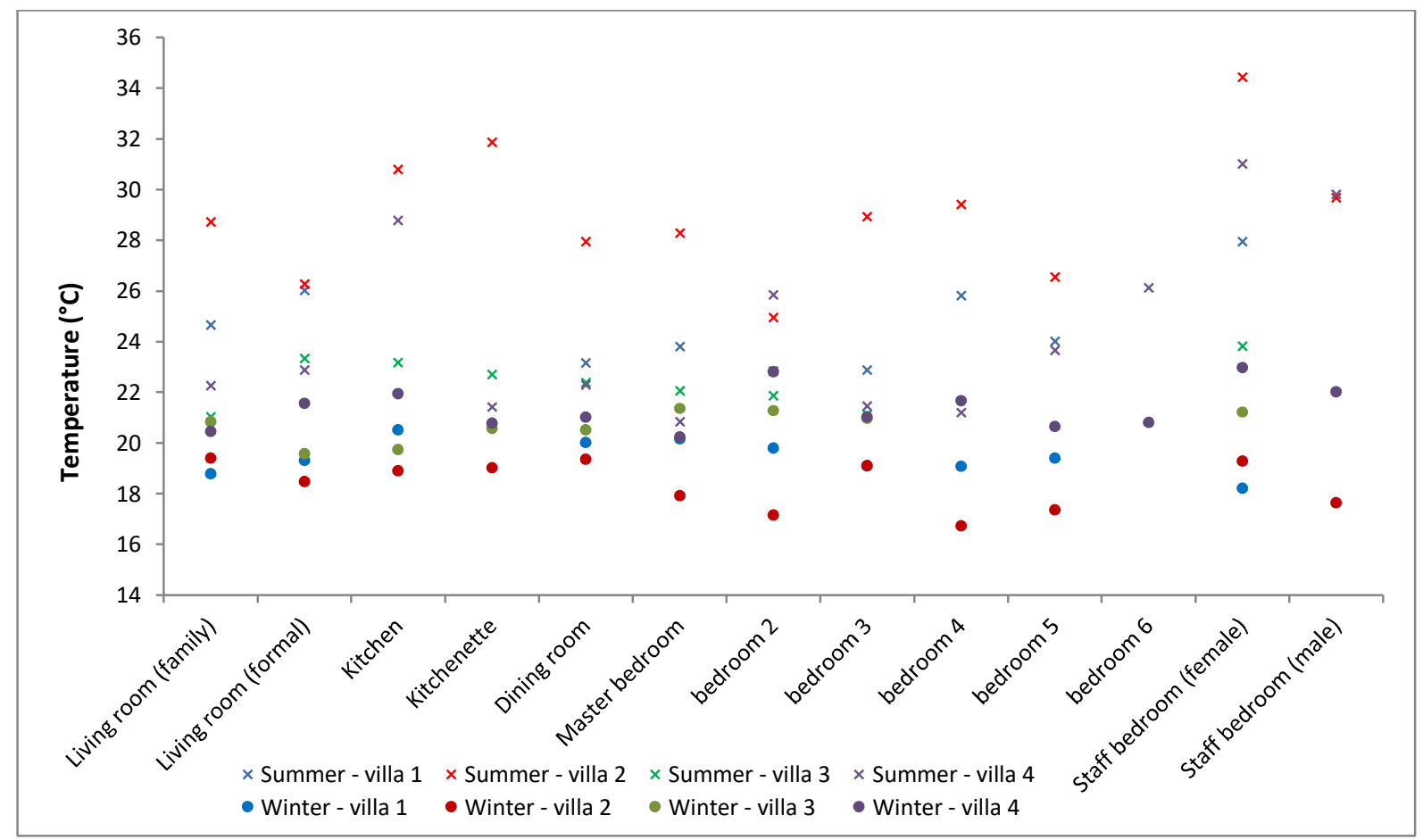

Figure 4 - Average room temperatures during summer (June, July, August) and winter (December, January, February)

Note: Rooms present in each villa are specifically marked, i.e. only villa 4 has a bedroom 6

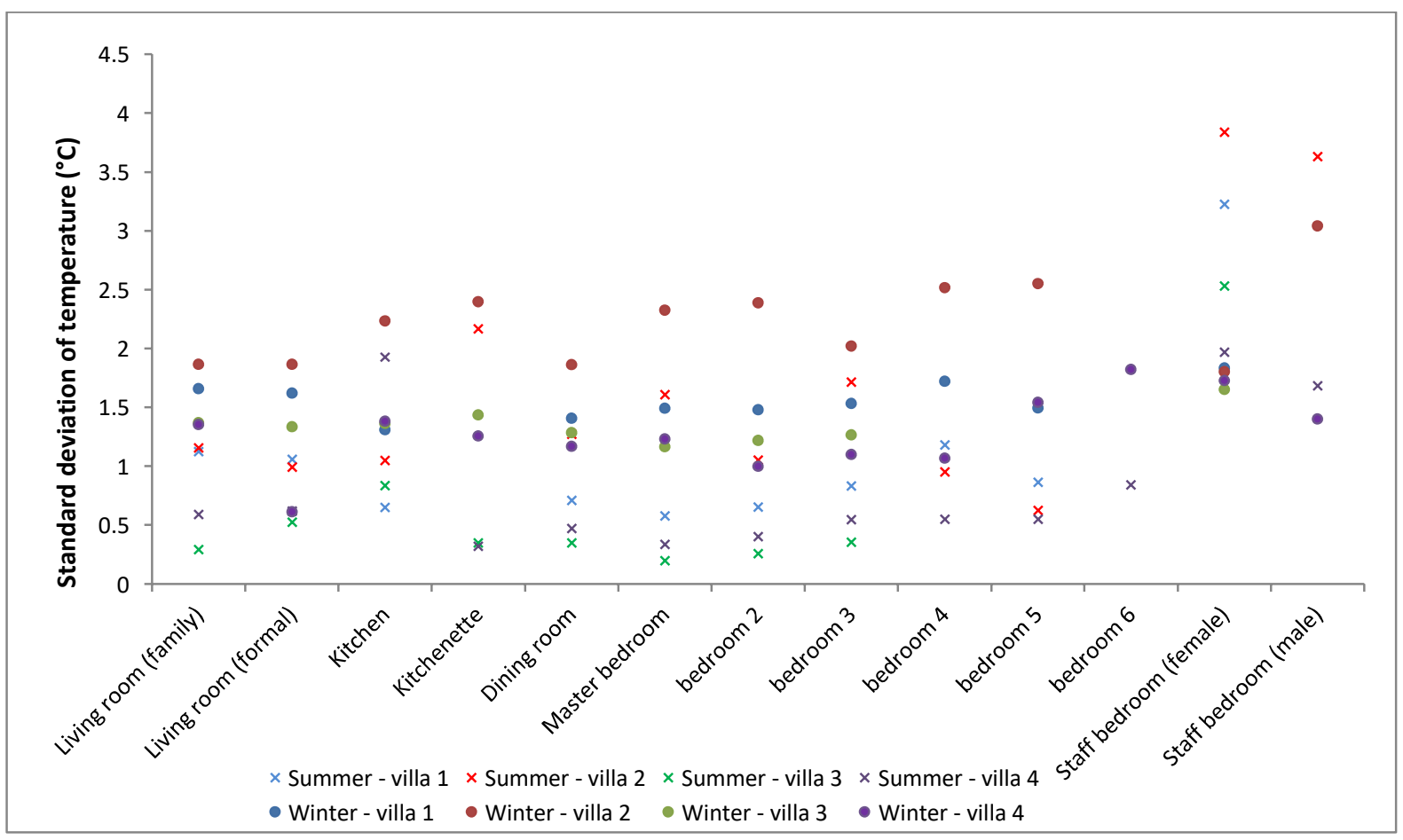

Figure 5 - Standard deviations of temperatures in individual room during summer (June, July, August) and winter (December, January, February) 


\subsubsection{The impact of occupants}

The impact of occupants on energy use, including household size (number of occupants), household income, and occupant energy-use behaviours, was also explored in the monitoring study. As shown in table 6, villas with more occupants (villas 1 and 4) had higher annual energy use intensities, higher energy use intensities during periods when the AC was switched off, as well as higher plug load intensities. Although data from a greater sample of cases is required to better determine the impact of household size on energy use, such findings suggest a positive association between the two. Regarding household income, no clear association with energy use was detected when comparing the four villas. The percentage of income spent on energy in each villa however was found to be relatively low (table 6), especially when compared with UK households that spent on average $4.4 \%$ of their total expenditure on energy in 2015 [51]. Low energy expenditure is likely due to the highly subsidized electricity tariffs, which enable lower income households to afford larger villas as well as the running costs associated with high appliance use.

Table 6 - Household size and income parameters

\begin{tabular}{|c|c|c|c|c|}
\hline & Villa 1 & Villa 2 & Villa 3 & Villa 4 \\
\hline Number of occupants & 9 & 6 & 7 & 12 \\
\hline Plug load intensity (W/m2) & 29.1 & 9.5 & 16.4 & 22.3 \\
\hline Annual energy use $\left(\mathrm{kWh} / \mathrm{m}^{2}\right)$ & 219 & 171 & 174 & 225 \\
\hline $\begin{array}{c}\text { Average energy use per week } \\
\text { when AC switched off ( } \mathrm{kWh} / \mathrm{m}^{2} / \text { week) }\end{array}$ & 3.5 & 0.9 & 1.4 & 2.6 \\
\hline Annual electricity bill (KWD) & $\begin{array}{c}174 \\
(\$ 576) \\
\end{array}$ & $\begin{array}{c}194 \\
(\$ 642) \\
\end{array}$ & $\begin{array}{c}245 \\
(\$ 811) \\
\end{array}$ & $\begin{array}{c}363 \\
(\$ 1202) \\
\end{array}$ \\
\hline Annual household income (KWD) & $\begin{array}{c}27,600 \\
(\$ 91,356)\end{array}$ & $\begin{array}{c}32,400 \\
(\$ 107,244)\end{array}$ & $\begin{array}{c}18,000 \\
(\$ 59,580)\end{array}$ & $\begin{array}{c}36,000 \\
(\$ 119,160)\end{array}$ \\
\hline Percentage of income spent on energy (\%) & 0.6 & 0.6 & 1.4 & 1.0 \\
\hline
\end{tabular}

Note: conversions to US dollars based on rates as of June 6, 2018 (1KWD=\$3.31)

Regarding occupant energy consuming behaviours, key findings are summarised in table 7 , and discussed below:

- AC operation and control

All households switched their central AC on for about 7-9 months of the year; even when outdoor conditions were relatively mild (from March till May and September till November). Occupants in villas 2 and 4 also tended to open windows during such mild periods, a behaviour likely to affect AC performance and energy use. Similarly, during periods of travel when most occupants vacated the building, homeowners, with exception to those in villa 1 , made no adjustments to their central AC thermostat settings (leaving cooling on all day at the same set points). In villa 1 , increasing thermostats by $1^{\circ} \mathrm{C}$ during a one month holiday in July contributed to the reduction in energy use that month compared to June and August; July consumption was about $37 \%$ and $39 \%$ lower than in June and August respectively, due both to lower thermostat settings and no appliance and lighting use that month. Reducing appliance use in summer has a double effect on energy use; it directly reduces electricity use, but also reduces heat gains and so reduces cooling energy use by the AC. Thermostat adjustments during periods of travel, is a behaviour likely to be influenced by the structure of the household; villas 1 consists of a working couple with younger children that travel together, whereas villas 2 and 4 in particular consist of more diverse families with different travel routines (such villas are rarely empty at any given time). Similarly the duration of travel may also 
influence such behaviour; occupants in villa 3, did not travel for more than a week throughout the monitoring period, and were perhaps not motivated to adjust thermostats.

Regarding the use of split units, which are largely located in staff bedrooms, it was observed that as external temperatures increased in summer, staff in all villas, tended to keep units switched on almost all day (even when rooms are unoccupied). Temperatures recorded at such rooms were also found to be notably higher than the temperature the split unit was set to. This was especially the case in villas 1, 2, and 4 which had relatively older split units. Split units were also used in the main kitchens in villas 2, 3, and 4. During summer in villa 3, the unit was operated on a 24 hour basis with the homeowner explaining that "when it's hot outside the kitchen units are always on, even at night. We have things in there we don't want to spoil". Kitchen units in villas 2 and 4 however were switched off in the late evenings by staff.

\section{- AC maintenance}

All households did not undertaken regular servicing but called professional service staff only when there was a problem with their AC plant. Homeowners in villas 1, 2 and 4 also opted to clean their $A C$ external filters themselves before first operating their central units in spring, while homeowners of villa 3 cleaned AC filters one month after AC operation. Such behaviour may have led to AC defects remaining undetected, especially as all homeowners reported that, within a few weeks of operation, technicians were called in to fix some developing problem. Although all homeowners were able to notice when there was a problem with their AC, they generally did not understand what the solution was and were happy as long as it was rapidly fixed. Lack of regular servicing thus seems to lead to distress maintenance/purchases in which homeowners were willing to accept quick solutions provided by the technician at a time when they and others are overheating. In such cases technicians are likely to make changes that are the easiest and fastest to make, but are not always those that lead to the most efficient future operation of the unit.

- Household cleaning and appliance use

In all villas, as is common in Kuwait, staff are responsible for household cleaning and cooking activities, all of which require the use of energy consuming appliances such as washing machines, dryers etc. Both household size and a strong desire for comfort and convenience are likely to impact on the frequency of household chores and appliances use. In villa 4 for example, which has the highest number of occupants, laundry is carried out daily for several hours with homeowners noting that "we like our clothes ready quick... We also don't like wearing new clothes without washing them first". Similarly in villa 1 , which has four teenage children, appliance use is relatively high, with homeowner stating that "when the kids are home the downstairs TV is always on and their mobile, tablet and lap top chargers are always plugged in. Kitchen equipment, the kettle, toaster are used countless times!" Table 8 further presents a breakdown of plug loads for appliances in each villa, and figure 6 presents typical weekend and weekday appliance use schedules.

- Lighting use and control

In villas 1 and 4 , occupants tended to switch lights on during the day, which as explained by homeowners during the interviews, is due to limited daylight in the building. Both villas 1 and 4 have dense, cubic shapes and are in very close proximity to adjacent villas compared to villas 2 and 3 
which are well setback from neighboring villas, have larger windows and more natural daylight. During the evenings, all villas, with exception to villa 2, tended to use lights generously even in some unoccupied rooms/spaces. Homeowners in all villas (except villa 4) also tended to use more LED than incandescent bulbs throughout their homes as indicated in table 7. Figure 6 also present typical weekday and weekend lighting use schedules in each villa.

Table 7 - A summary of key occupant energy consuming behaviours

\begin{tabular}{|c|c|c|c|c|}
\hline & Villa 1 & Villa 2 & Villa 3 & Villa 4 \\
\hline $\begin{array}{c}\text { AC period of } \\
\text { operation }\end{array}$ & $\begin{array}{l}8 \text { months } \\
\text { (Mar-Oct) }\end{array}$ & $\begin{array}{l}7 \text { months } \\
\text { (Apr-Oct) }\end{array}$ & $\begin{array}{c}8 \text { months } \\
\text { (Mar-Oct) }\end{array}$ & $\begin{array}{c}9 \text { months } \\
\text { (End of Feb-mid Nov) }\end{array}$ \\
\hline $\begin{array}{l}\text { Central AC thermostat } \\
\text { settings during } \\
\text { operation (when } \\
\text { occupants present) }\end{array}$ & $\begin{array}{l}\text { Thermostats set to } \\
\text { automatic at } 23^{\circ} \mathrm{C} \\
\text { (ground and first } \\
\text { floors). }\end{array}$ & $\begin{array}{l}\text { Thermostats set to } \\
\text { automatic at } 25^{\circ} \mathrm{C} \\
\text { (ground and first floors) }\end{array}$ & $\begin{array}{l}\text { Thermostats set to } \\
\text { automatic at } 23^{\circ} \mathrm{C} \\
\text { (ground floor), } \\
21^{\circ} \mathrm{C} \text { (first floor) and } \\
22^{\circ} \mathrm{C} \text { (second floor). }\end{array}$ & $\begin{array}{c}\text { Thermostat set to } \\
\text { automatic at } 21^{\circ} \mathrm{C} \text { (first } \\
\text { floor), } 23^{\circ} \mathrm{C} \text { (basement } \\
\text { and half of ground floor) } \\
\text { and } 25^{\circ} \mathrm{C} \text { (half of } \\
\text { ground floor) }\end{array}$ \\
\hline $\begin{array}{l}\text { Split unit AC control } \\
\text { during periods of } \\
\text { operation (when } \\
\text { occupants present) }\end{array}$ & $\begin{array}{l}\text { Unit in staff bedroom } \\
\text { switched on when } \\
\text { room is occupied only } \\
\text { but during summer } \\
\text { unit often left on } \\
\text { when room is vacant. } \\
\text { Settings ranged from } \\
18-21^{\circ} \mathrm{C}\end{array}$ & $\begin{array}{l}\text { Units switched on when } \\
\text { rooms are occupied. } \\
\text { During summer units } \\
\text { often left on when } \\
\text { rooms are vacant. } \\
\text { Settings ranged from } \\
19-21^{\circ} \mathrm{C}\end{array}$ & $\begin{array}{l}\text { Unit in staff bedroom } \\
\text { often left on when } \\
\text { room is vacant. Kitchen } \\
\text { unit always on even } \\
\text { when vacant (at night). } \\
\text { Settings ranged from } \\
20-22^{\circ} \mathrm{C}\end{array}$ & $\begin{array}{l}\text { Units switched on when } \\
\text { rooms are occupied. } \\
\text { During summer units } \\
\text { often left on when } \\
\text { rooms are vacant. } \\
\text { Settings ranged from } \\
19-22^{\circ} \mathrm{C}\end{array}$ \\
\hline $\begin{array}{c}\text { Time main occupants } \\
\text { vacated villa for travel } \\
\text { during the year }\end{array}$ & $\begin{array}{l}4 \text { weeks } \\
\text { (in July) }\end{array}$ & $\begin{array}{c}6 \text { weeks } \\
\text { (mid-July till end of } \\
\text { August) }\end{array}$ & $\begin{array}{c}1 \text { week } \\
\text { (mid-August) }\end{array}$ & $\begin{array}{c}3 \text { weeks } \\
\text { (mid-August till end of } \\
\text { August) }\end{array}$ \\
\hline $\begin{array}{l}\text { Number of occupants } \\
\text { in villa after main } \\
\text { occupants vacated }\end{array}$ & None & 1 male household staff & None & $\begin{array}{l}2 \text { household occupants } \\
\text { and } 6 \text { household staff }\end{array}$ \\
\hline $\begin{array}{l}\text { AC control during } \\
\text { periods of travel } \\
\text { (when main occupants } \\
\text { vacated building) }\end{array}$ & $\begin{array}{l}\text { Central } \mathrm{AC} \text { thermostat } \\
\text { increased by } 1^{\circ} \mathrm{C} \text { in } \\
\text { July to } 24^{\circ} \mathrm{C} \text { and back } \\
\text { down to } 23^{\circ} \mathrm{C} \text { in } \\
\text { August. Staff split unit } \\
\text { switched off. }\end{array}$ & $\begin{array}{l}\text { Central AC thermostat } \\
\text { left unchanged at } 25^{\circ} \mathrm{C} \\
\text { throughout. All split } \\
\text { units switched off. }\end{array}$ & $\begin{array}{l}\text { Central AC thermostat } \\
\text { left unchanged at } \\
21-23^{\circ} \mathrm{C} \text {. All split units } \\
\text { switched off. }\end{array}$ & $\begin{array}{l}\text { Central AC thermostat } \\
\text { left unchanged at } \\
21-25^{\circ} \mathrm{C} \text {. Split units } \\
\text { operated as normal as } \\
\text { many occupants } \\
\text { remained at home. }\end{array}$ \\
\hline $\begin{array}{l}\text { Window and curtain } \\
\text { control }\end{array}$ & $\begin{array}{l}\text { Windows not opened } \\
\text { when AC on. } \\
\text { Curtains pulled down } \\
\text { in most rooms during } \\
\text { the summer. }\end{array}$ & $\begin{array}{l}\text { Windows often opened } \\
\text { in spring and autumn } \\
\text { (even when AC on). } \\
\text { Curtains pulled down in } \\
\text { unoccupied rooms } \\
\text { during the summer. }\end{array}$ & $\begin{array}{c}\text { Windows not opened } \\
\text { when AC on. Curtains } \\
\text { pulled down in } \\
\text { unoccupied rooms } \\
\text { during the summer. }\end{array}$ & $\begin{array}{l}\text { Windows often opened } \\
\text { in spring and autumn } \\
\text { (even when AC on). } \\
\text { Curtains pulled down in } \\
\text { unoccupied rooms } \\
\text { during the summer. }\end{array}$ \\
\hline AC maintenance & $\begin{array}{c}\text { AC filters cleaned } \\
\text { before AC operation in } \\
\text { spring. Reactive } \\
\text { servicing during } \\
\text { period of operation. }\end{array}$ & $\begin{array}{l}\text { AC filters cleaned } \\
\text { before AC operation in } \\
\text { spring. Reactive } \\
\text { servicing during period } \\
\text { of operation. }\end{array}$ & $\begin{array}{l}\text { AC filters cleaned one } \\
\text { month after AC } \\
\text { operation. Reactive } \\
\text { servicing during period } \\
\text { of operation. }\end{array}$ & $\begin{array}{l}\text { AC filters cleaned before } \\
\text { AC operation in spring. } \\
\text { Reactive servicing } \\
\text { during period of } \\
\text { operation. }\end{array}$ \\
\hline Space heating & No space heating used & $\begin{array}{l}2 \text { electric heaters used } \\
\text { intermittently in } \\
\text { December and January }\end{array}$ & $\begin{array}{l}3 \text { electric heaters used } \\
\text { intermittently in } \\
\text { December and January }\end{array}$ & $\begin{array}{l}3 \text { electric heaters used } \\
\text { intermittently in } \\
\text { December and January }\end{array}$ \\
\hline $\begin{array}{l}\text { Household cleaning } \\
\text { and appliance usage }\end{array}$ & $\begin{array}{c}1 \text { washing machine } \\
\text { cycle per day, daily } \\
\text { ironing, daily cooking } \\
\text { (3 meals) }\end{array}$ & $\begin{array}{l}\text { 1-2 washing machines } \\
\text { cycles per day, daily } \\
\text { ironing, daily cooking } \\
\text { ( } 2 \text { meals) }\end{array}$ & $\begin{array}{c}\text { Continuous use of } \\
\text { washing and drying } \\
\text { machines, daily ironing, } \\
\text { daily cooking ( } 3 \text { meals) }\end{array}$ & $\begin{array}{l}\text { Continuous use of } \\
\text { washing and drying } \\
\text { machines, daily ironing, } \\
\text { daily cooking ( } 3 \text { meals) }\end{array}$ \\
\hline $\begin{array}{l}\text { Light usage and } \\
\text { control }\end{array}$ & $\begin{array}{l}\text { Some lights switched } \\
\text { on during the day. } \\
\text { Lights used generously } \\
\text { in the evenings even } \\
\text { in unoccupied rooms. } \\
\text { Number of bulbs: } 60 \\
\text { LED; } 20 \text { incandescent }\end{array}$ & $\begin{array}{l}\text { Lights not switched on } \\
\text { during the day and very } \\
\text { minimally used in the } \\
\text { evenings } \\
\text { Number of bulbs: } 65 \\
\text { LED; } 35 \text { incandescent }\end{array}$ & $\begin{array}{l}\text { Lights not switched on } \\
\text { during the day. Lights } \\
\text { used generously in the } \\
\text { evenings even in some } \\
\text { unoccupied rooms. } \\
\text { Number of bulbs: } 110 \\
\text { LED; } 40 \text { incandescent }\end{array}$ & $\begin{array}{l}\text { Some lights switched on } \\
\text { during the day. Lights } \\
\text { used generously only in } \\
\text { occupied rooms in the } \\
\text { evenings. } \\
\text { Number of bulbs: } 90 \\
\text { LED; } 110 \text { incandescent }\end{array}$ \\
\hline
\end{tabular}


Table 8-Appliance plug loads in each villa

\begin{tabular}{|c|c|c|c|c|c|c|c|c|}
\hline & \multicolumn{2}{|c|}{ Villa 1} & \multicolumn{2}{|c|}{ Villa 2} & \multicolumn{2}{|c|}{ Villa 3} & \multicolumn{2}{|c|}{ Villa 4} \\
\hline & Quantity & $\begin{array}{c}\text { Total } \\
\text { wattage }\end{array}$ & Quantity & $\begin{array}{c}\text { Total } \\
\text { wattage }\end{array}$ & Quantity & $\begin{array}{c}\text { Total } \\
\text { wattage }\end{array}$ & Quantity & $\begin{array}{c}\text { Total } \\
\text { wattage }\end{array}$ \\
\hline TVS & 3 & 590 & 3 & 620 & 4 & 715 & 9 & 1345 \\
\hline TV receiver & 3 & 72 & 3 & 72 & 5 & 120 & 6 & 144 \\
\hline Fridge & 3 & 440 & 1 & 240 & 2 & 370 & 4 & 650 \\
\hline Freezer & 1 & 350 & 1 & 350 & 2 & 440 & 3 & 540 \\
\hline Toaster & 1 & 900 & 1 & 800 & 1 & 900 & 2 & 1700 \\
\hline Kettle & 1 & 1800 & 1 & 1200 & 2 & 2400 & 3 & 3600 \\
\hline Microwave & 1 & 1200 & 1 & 600 & 1 & 800 & 1 & 800 \\
\hline Water cooler & - & - & 1 & 70 & - & - & - & - \\
\hline Coffee machine & 1 & 510 & - & - & 1 & 510 & 2 & 1200 \\
\hline Blender & 1 & 280 & - & - & 1 & 280 & 1 & 280 \\
\hline Fryer & 1 & 1000 & - & - & & & & \\
\hline Washing machine & \multirow[t]{2}{*}{1} & \multirow[t]{2}{*}{1800} & 1 & 350 & 1 & 350 & 3 & 875 \\
\hline Clothes dryer & & & - & - & 1 & 1800 & 1 & 2000 \\
\hline Water pump & 1 & 725 & - & - & 1 & 725 & 1 & 725 \\
\hline Laptop & 1 & 40 & 1 & 50 & 1 & 40 & 4 & 120 \\
\hline Desktop & - & - & 1 & 75 & - & - & - & - \\
\hline Phone charger & 8 & 32 & 5 & 20 & 4) & 16 & 12 & 48 \\
\hline Tablet charger & 2 & 20 & 2 & 20 & 1 & 10 & 3 & 30 \\
\hline Iron & 1 & 1100 & 1 & 950 & 1 & 1000 & 1 & 1100 \\
\hline Games console & - & - & - & - & 1 & 253 & 1 & 250 \\
\hline Alarm system & - & - & - & - & 1 & 30 & - & - \\
\hline Massage chair & - & - & - & - & 1 & 200 & - & - \\
\hline Oxygen condenser & - & - & - & - & - & - & 1 & 500 \\
\hline Electric bed & - & - & - & - & - & - & 1 & 350 \\
\hline Hair dryer & 1 & 710 & & & 1 & 600 & 2 & 1800 \\
\hline TOTAL WATTAGE & - & 11569 & - & 5417 & - & 11559 & - & 18057 \\
\hline WATTAGE/M² & - & 29.1 & - & 9.5 & - & 16.4 & - & 22.3 \\
\hline
\end{tabular}




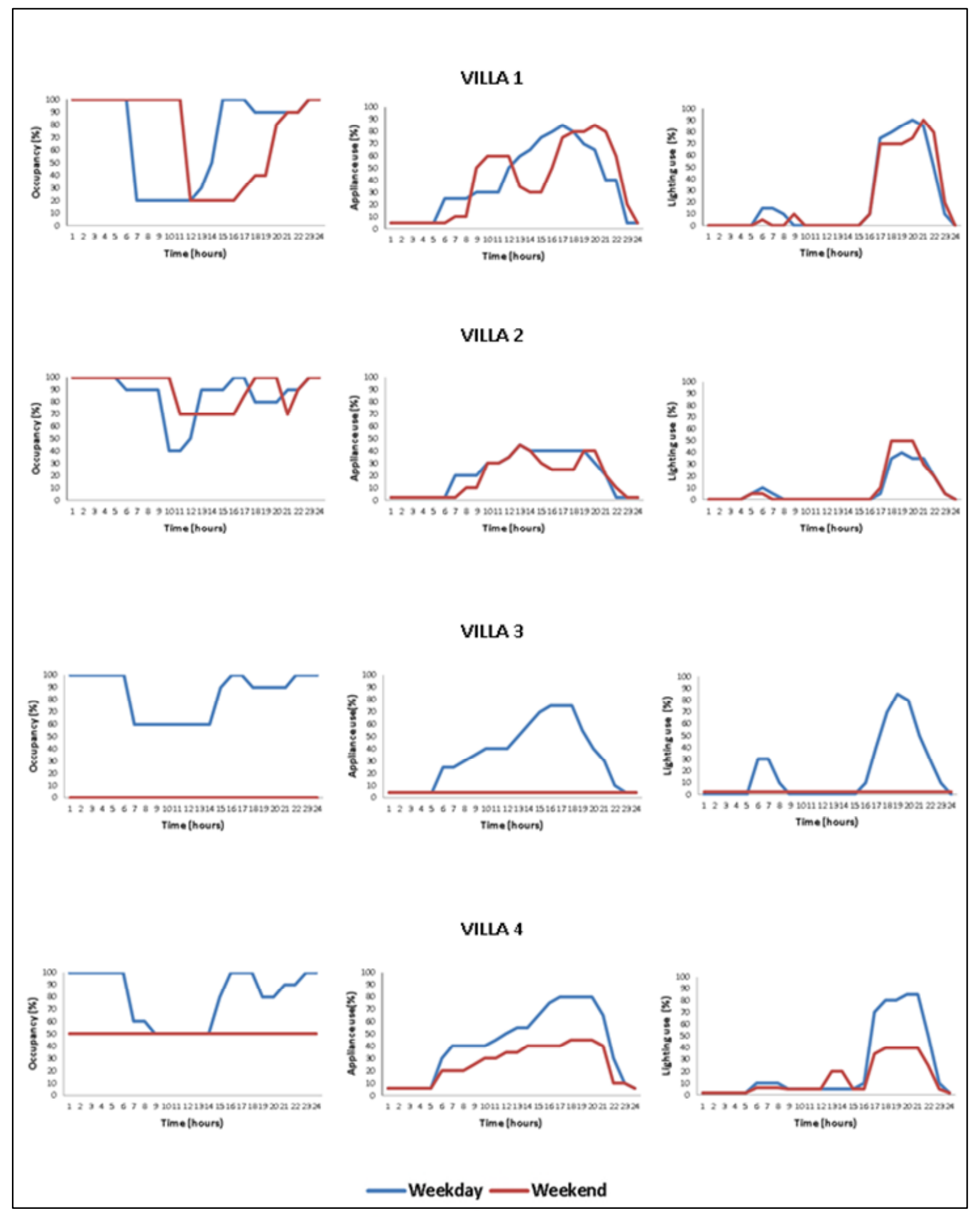

Figure 6 - Typical weekday and weekend occupancy, appliance and lighting schedules in the case study villa 


\subsection{Modelling results}

\subsubsection{Model validation and constraints}

Before interpreting modelling results, model validation and constraints are briefly discussed below. Table 9 presents the extent to which the four villa models comply with standard statistical criteria for model calibration. As shown, statistical indices for villas 2 and 3 are within the criteria while those of villas 1 and 3 are not. Models of villas 1 and 3 however are considered valid in light of the purpose of the modelling exercise of this study, which is primarily to assist in understanding the energy performance of individual villas given what empirical data is available. Attempting to reduce discrepancy between modelled and measured performance, without an underpinning logic supported by empirical data would be inappropriate.

It is widely acknowledged that building energy modelling is a complex process with many parameters that carry an associated level of uncertainty $[46,47]$. Great discrepancies between modelled and measured energy performance have frequently been reported by many studies, often with a limited understanding of the reasons for this [11-13]. In this study, while model development followed a systematic process and inputs were largely informed by real data, discrepancies in villas 1 and 3 could possibly be due to assumptions regarding fabric insulation and AC COP. Inputs associated with these parameters were not based on forensic investigations but on visual examinations, a consideration of building age, and MEW code requirements (as noted in table 2 above). Similarly, some discrepancy could also be due to differences between actual and simulated building operation data (associated with occupant behaviours and schedules); especially as real behaviour cannot be fully replicated in a simulation. The sections below will provide further analysis of simulated and measured performance in the four villas.

Table 9 - Calibration of villas relative to statistical criteria for calibration in compliance with [48-50]

\begin{tabular}{|c|c|c|c|c|c|c|c|}
\hline & \multirow[b]{2}{*}{ Villa 1} & \multirow[b]{2}{*}{ Villa 2} & \multirow[b]{2}{*}{ Villa 3} & \multirow[b]{2}{*}{ Villa 4} & \multicolumn{3}{|c|}{ Monthly criteria } \\
\hline & & & & & $\begin{array}{c}\text { ASHREA } \\
\text { Guideline } 14\end{array}$ & IPMV & FEMB \\
\hline MBE (\%) & -20 & -3 & 11 & -1 & \pm 5 & \pm 20 & \pm 5 \\
\hline CVRMSE (\%) & 37 & 15 & 23 & 12 & 15 & - & 15 \\
\hline
\end{tabular}

\subsubsection{Simulated vs. measured energy consumption}

A comparison of annual measured and simulated energy use, normalized by floor area, is presented in figure 7 . This shows relatively greater variation (about $22 \%$ ) in villa 1 compared to the other villas. To enable further comparisons, figures 8-9 illustrate measured and simulated weekly energy consumption in Watts per $\mathrm{m}^{2}$ against external temperature in each villa during periods the AC is switched ON and OFF. Graphs are presented in this way to illustrate the two separate relationships which occur due to different power inputs into the building; when the AC is OFF there is a fixed power input, while as soon as the AC is ON the amount of energy that goes into a building changes. Such graphs also provide some insight into the technical performance of villas; the gradient 
of the lines (shown by equations on each graph) provide an indication of heat gains from the building fabric and ventilation in response to external temperature variations. All graphs exclude periods when occupants were away on vacation.

Comparing gradients of the simulated and measured graphs when the AC is ON (figures 8 and 9) it appears that villas 1 and 4 are about $60 \%$ and $40 \%$ more efficient respectively than the models suggests, while villas 2 and 3 are about $30 \%$ and $40 \%$ less efficient. Villa 2, in particular, had the highest increase in measured energy use per temperature rise $(1255 \mathrm{~W}$ for every degree of cooling) compared to other villas (figure 8). This is likely because of villa 2's older, inefficient central AC units and uninsulated, single glazed fabric, with many exposed surfaces and skylight openings. Villa 1, however, also uninsulated and single glazed, did not significantly increase its measured energy use as external temperatures rose; it required about 4 times less energy (296W) for every degree of cooling than villa 2, and about 3 times less energy than the insulated and double glazed villas 3 and 4 . Although this, in part, could be due to villa 1's newer efficient central AC units (installed in 2013), smaller building size and less exposed surface areas, such relatively low cooling energy use also suggests there could be a potential difference in the actual fabric performance and/or AC performance of the villa compared to assumptions made. To better explain this, detailed forensic investigation of the building is required, which is beyond the scope of the current study.

A smoother transition was also observed between measured AC ON/OFF in all villas compared to simulated AC ON/OFF (figures 8-9). This is because central AC cooling was modelled to be switched on and off at a specific day in the year (as found during the monitoring study). In reality however, although occupants switched their central AC's on and off at a specific day, during such time (March/April and October/November) external temperatures were relatively mild, and occupants also tended to adjust thermostat settings more. This behaviour is likely to have caused the smoother transition between measured $A C$ on/off compared to simulated $A C$ on/off (where no such transition was modelled).

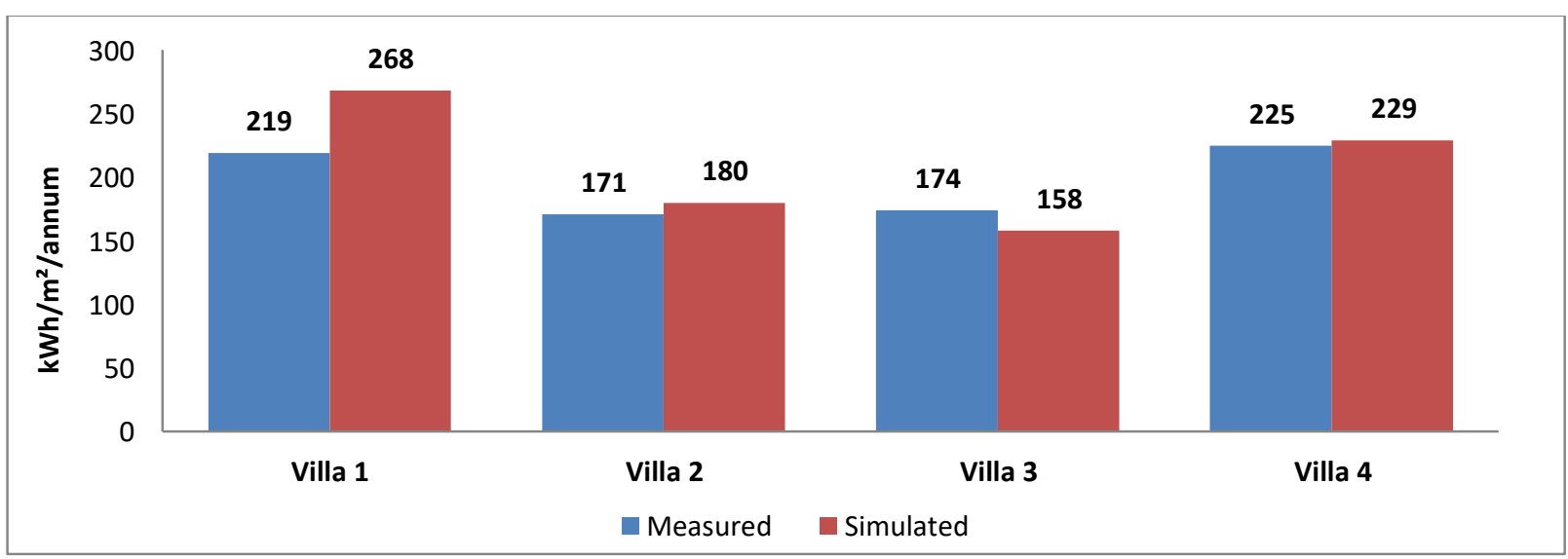

Figure 7 - Measured vs. simulated annual energy consumption ( $\mathrm{kWh} / \mathrm{m}^{2} /$ annum) 


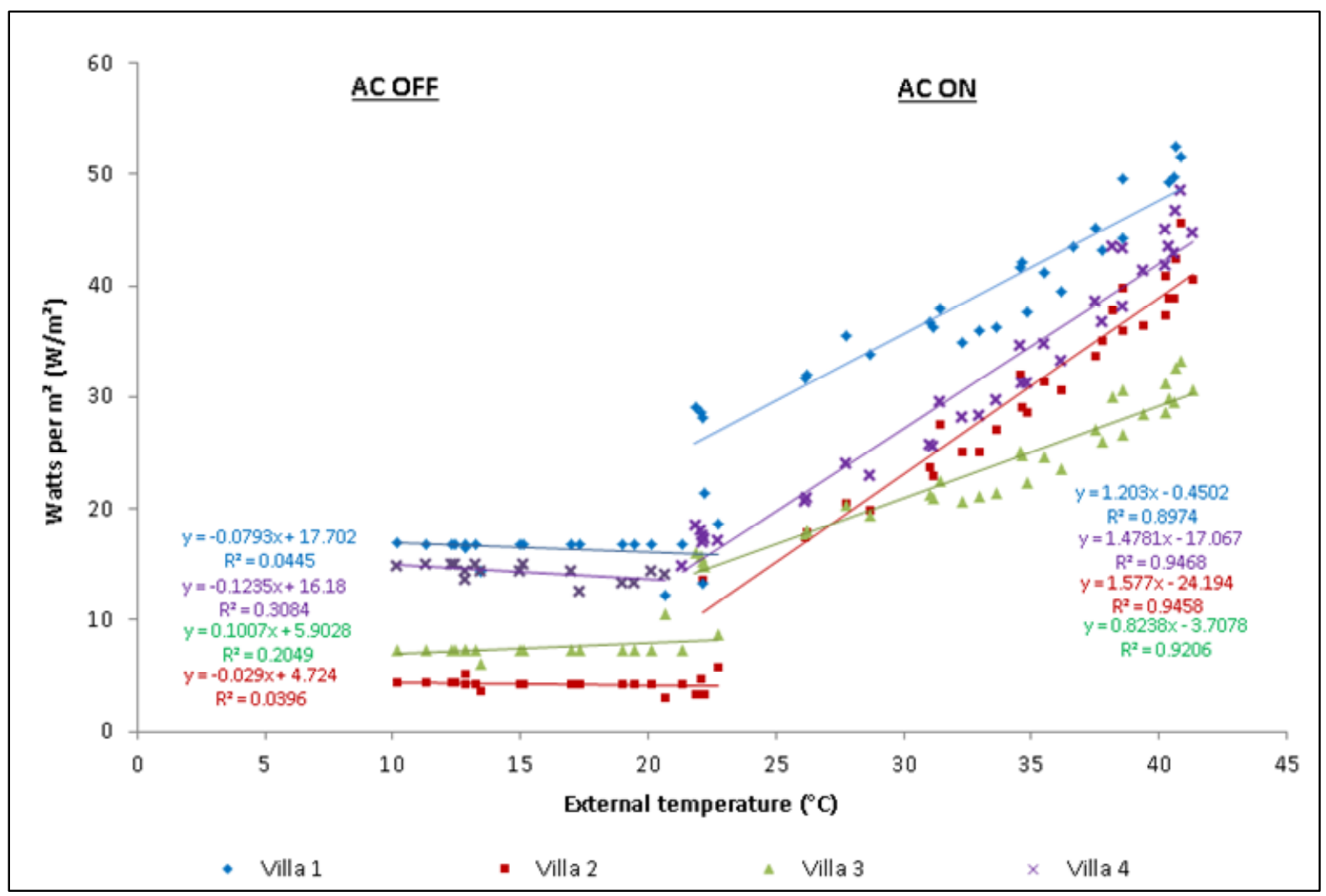

Figure 8- Simulated weekly energy use in Watts per $\mathrm{m}^{2}$ vs. external temperature for periods the AC is ON and OFF

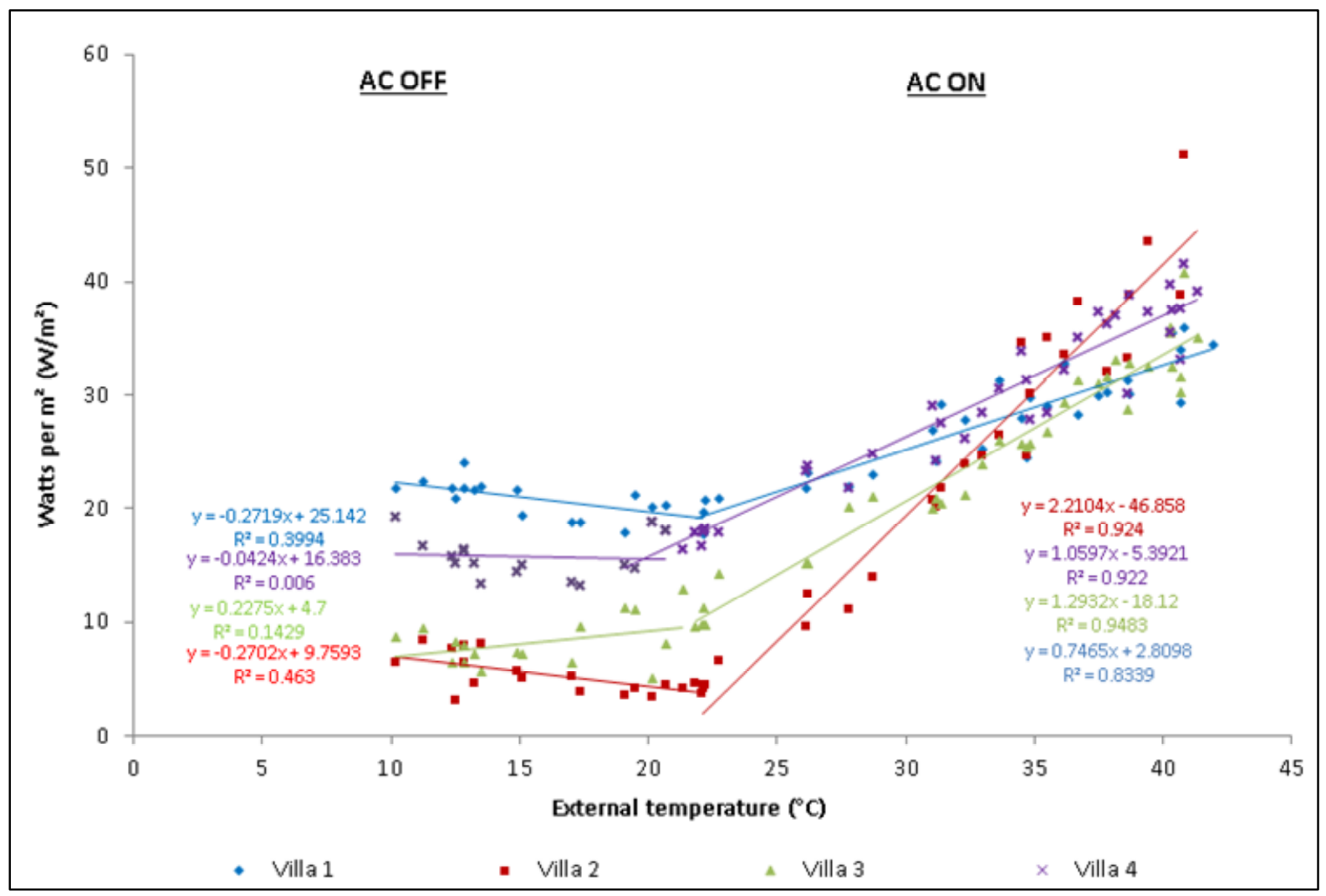

Figure 9 - Measured weekly energy use in Watts per $\mathrm{m}^{2}$ vs. external temperature for periods the $A C$ is $O N$ and OFF 


\subsubsection{End-use energy distribution}

Figures 10 presents modelled end-use energy breakdowns in each villa (in $\mathrm{kWh} / \mathrm{m}^{2}$ ); no disaggregated electricity data was collected as part of this study and so no comparisons can be made with measured. Figure 11 presents modelled end-use energy breakdowns as a percentage of total energy use. As shown, energy consumption for space cooling varied, ranging from $50 \%$ to $75 \%$ of overall energy use in different villas. Figure 12 further illustrates the cooling load breakdowns of each simulated villa. In villa 2 , uninsulated and single glazed, $70 \%$ of cooling was found to be due to heat gains from the fabric and ventilation/infiltration, with solar gains also being relatively important. In villa 1 , however, which is of a similar fabric and age to villa 2 , cooling load due to appliance use was the dominant factor. This could, in part, be due to a larger number of younger occupants using more electric appliances as noted in section 4.1 .2 above. Villa 4, which also has a large household size, has a large proportion of cooling driven by appliance use.

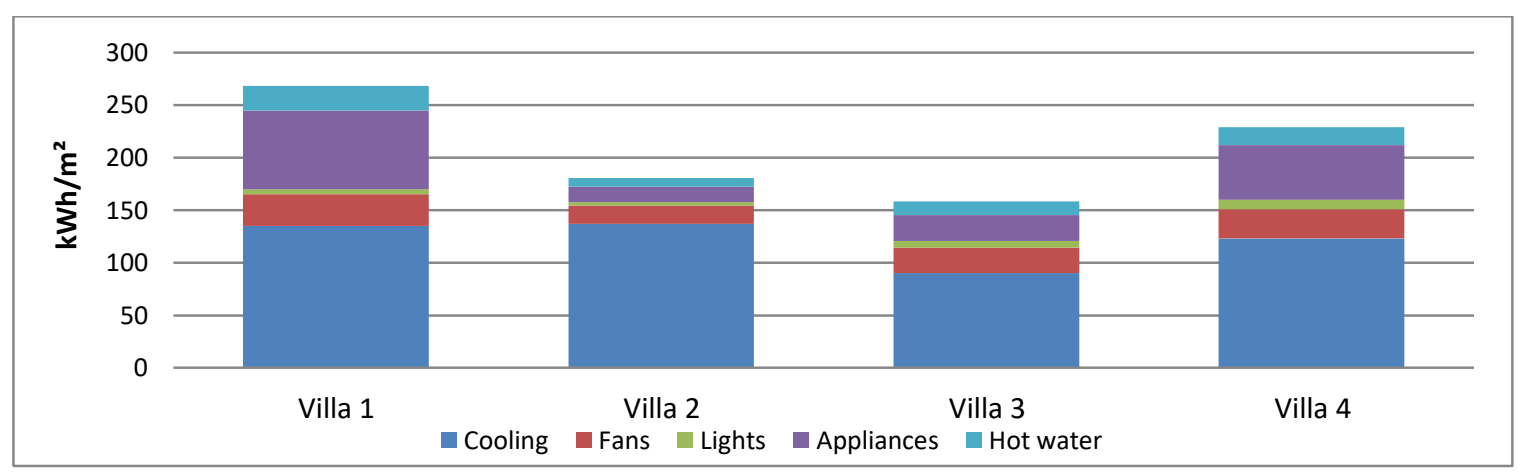

Figure 10 - Modelled end-use energy distribution in each villa

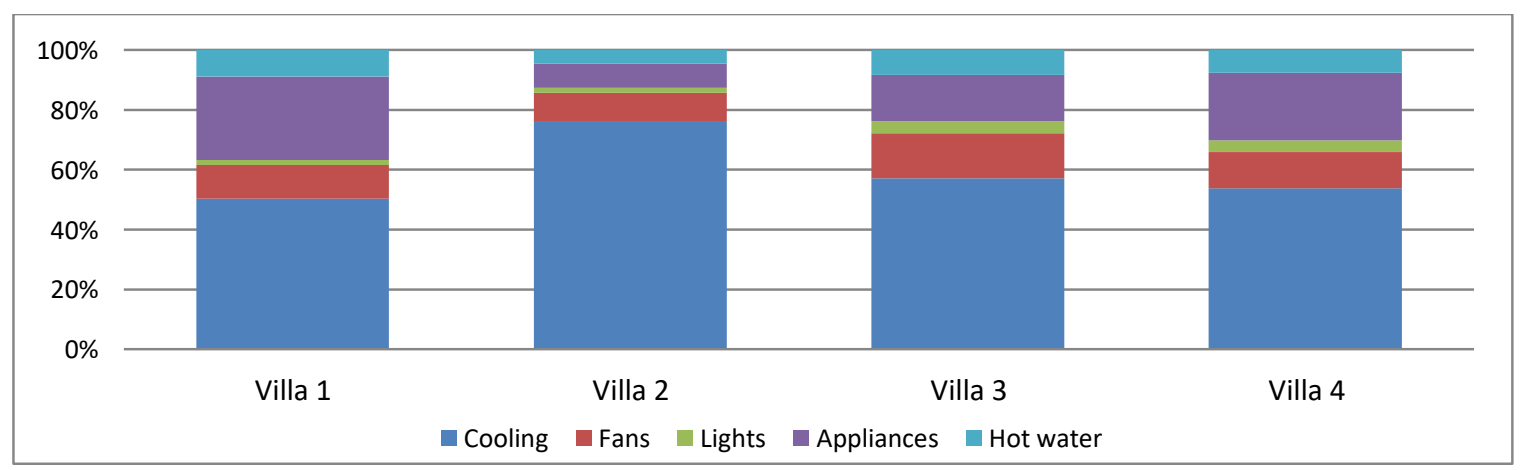

Figure 11- Percentage of modelled end-use energy distribution in each villa

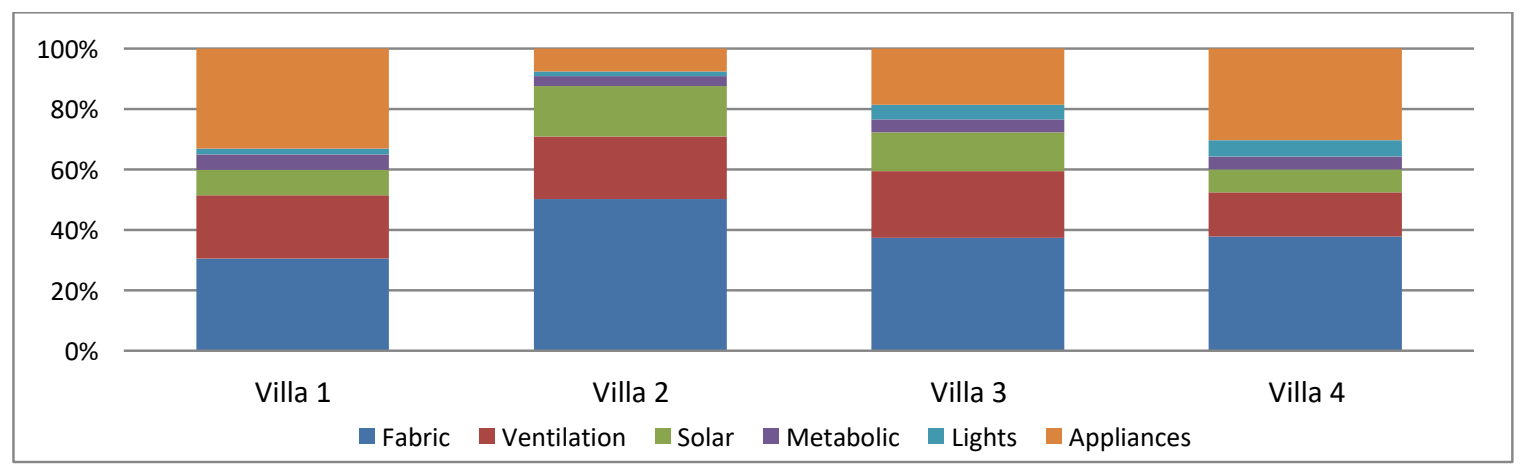

Figure 12 - Breakdown of modelled cooling load as a percentage in each villa 


\subsubsection{Sensitivity analysis}

To provide some insight into the importance of physical and social factors effecting energy use and the potential impact of different policy interventions, a differential sensitivity analysis was undertaken. For the older pre-code villas 1 and 2 a number of physical variations were tested to quantify the impact of fabric improvements to MEW 1983 code standards). In villa 2, where the AC units are over 35 years old, an additional variation accounting for improved AC efficiency was also tested. For the newer post-code villas however, a number of behavioral variations were tested including increasing thermostat set points by $1^{\circ} \mathrm{C}$, during the cooling period, and not cooling large unused rooms. Tables 10-12 illustrate the impact of such variations on energy use in each villa.

Upgrading villas 1 and 2 to 1983 code standards results in a 33\% and 56\% reduction in annual energy use and a saving of 70KWD (\$232) and 112KWD (\$371) in the annual electricity bills respectively (tables 10-11). If tariffs represent the actual cost of electricity, this intervention would amount to substantial savings of 1636 KWD (\$5416) and 2630KWD (\$8702) in annual electricity respectively. In villa 2 , only replacing the old $A C$ central units reduces annual energy use by $21 \%$,

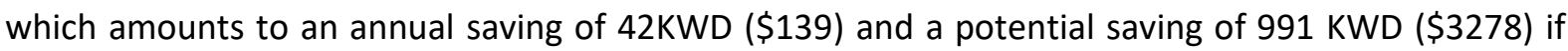
actual electricity production cost is considered. In villas 3 and 4 , an increase of $1^{\circ} \mathrm{C}$ in thermostat set points reduces annual electricity consumption by $7 \%$ and $11 \%$, while switching the cooling off in unused spaces reduces annual energy use by $10 \%$ and $5 \%$ respectively (table 12 ). As tables 10-12 indicate, current subsided electricity tariffs are unlikely to motivate homeowners to adjust their cooling behaviour or upgrade their building fabric as returns appear to be low. Therefore if electricity costs remain subsidized other forms of incentive or regulation are likely to be required to motivate energy efficiency interventions.

Table 10 - Savings due to fabric improvements in villa 1

\begin{tabular}{|c|c|c|c|c|c|}
\hline & \multicolumn{4}{|c|}{ Villa 1} & \multirow[b]{2}{*}{$\begin{array}{l}\text { All measures } \\
\text { combined }\end{array}$} \\
\hline & Wall insulation & Roof insulation & Double glazing & Infiltration & \\
\hline Savings (kWh/annum) & 29836 & 2097 & 1744 & 9469 & 34,811 \\
\hline $\begin{array}{l}\text { Savings as a percentage } \\
\text { of total kWh/annum (\%) }\end{array}$ & 29 & 2 & 2 & 9 & 33 \\
\hline $\begin{array}{c}\text { Financial savings at } \\
\text { current subsidised rate: } \\
0.002 \text { fils/kWD }\end{array}$ & $\begin{array}{l}60 \text { KWD } \\
(\$ 199)\end{array}$ & $\begin{array}{l}4 \text { KWD } \\
(\$ 13)\end{array}$ & $\begin{array}{l}3 \text { KWD } \\
(\$ 10)\end{array}$ & $\begin{array}{l}19 \text { KWD } \\
(\$ 63)\end{array}$ & $\begin{array}{l}70 \text { KWD } \\
(\$ 232)\end{array}$ \\
\hline $\begin{array}{l}\text { Financial savings at cost of } \\
\text { production: } 0.047 \mathrm{fils} / \mathrm{kWD}\end{array}$ & $\begin{array}{l}1402 \text { KWD } \\
(\$ 4641)\end{array}$ & $\begin{array}{l}98 \text { KWD } \\
(\$ 324)\end{array}$ & $\begin{array}{l}82 \text { KWD } \\
(\$ 271)\end{array}$ & $\begin{array}{c}445 \text { KWD } \\
(\$ 1473)\end{array}$ & $\begin{array}{l}1636 \text { KWD } \\
(\$ 5416)\end{array}$ \\
\hline
\end{tabular}

Note - improved u-values $\left(\mathrm{W} / \mathrm{m}^{2} .^{\circ} \mathrm{K}\right)$ walls 0.57 , roofs 0.39 , Glazing 3.33. Infiltration: $0.5 A C H$ 
Table 11 - Savings due to fabric improvements and AC system efficiency in villa2

\begin{tabular}{|c|c|c|c|c|c|c|}
\hline & \multicolumn{5}{|c|}{ Villa 2} & \multirow[b]{2}{*}{$\begin{array}{c}\text { All } \\
\text { measures } \\
\text { combined } \\
\end{array}$} \\
\hline & $\begin{array}{c}\text { Wall } \\
\text { insulation }\end{array}$ & $\begin{array}{c}\text { Roof } \\
\text { insulation }\end{array}$ & $\begin{array}{l}\text { Double } \\
\text { glazing }\end{array}$ & Infiltration & AC efficiency & \\
\hline Savings (kWh/annum) & 30728 & 2272 & 4226 & 11764 & 21078 & 55951 \\
\hline $\begin{array}{l}\text { Savings as a percentage } \\
\text { of total } \mathrm{kWh} / \text { annum (\%) }\end{array}$ & 31 & 2 & 4 & 12 & 21 & 56 \\
\hline $\begin{array}{c}\text { Financial savings at } \\
\text { current subsidised } \\
\text { rate:0.002fils/kWD }\end{array}$ & $\begin{array}{l}61 \mathrm{KWD} \\
(\$ 202)\end{array}$ & $\begin{array}{l}5 \mathrm{KWD} \\
(\$ 17)\end{array}$ & $\begin{array}{l}8 \mathrm{KWD} \\
(\$ 26)\end{array}$ & $\begin{array}{l}24 \mathrm{KWD} \\
\text { (\$79) }\end{array}$ & $\begin{array}{c}42 \mathrm{KWD} \\
\text { (\$139) }\end{array}$ & $\begin{array}{c}112 \mathrm{KWD} \\
(\$ 371)\end{array}$ \\
\hline $\begin{array}{l}\text { Financial savings at cost of } \\
\text { production: } 0.047 \text { fils/kWD }\end{array}$ & $\begin{array}{l}1444 \text { KWD } \\
(\$ 4778)\end{array}$ & $\begin{array}{l}107 \mathrm{KWD} \\
(\$ 354)\end{array}$ & $\begin{array}{l}199 \mathrm{KWD} \\
(\$ 658)\end{array}$ & $\begin{array}{l}553 \text { KWD } \\
(\$ 1830)\end{array}$ & $\begin{array}{l}991 \mathrm{KWD} \\
(\$ 3278)\end{array}$ & $\begin{array}{l}2630 \mathrm{KWD} \\
(\$ 8702)\end{array}$ \\
\hline
\end{tabular}

Note - improved u-values $\left(\mathrm{W} / \mathrm{m}^{2} .{ }^{\circ} \mathrm{K}\right)$ walls 0.57 , roofs 0.39 , Glazing 3.33. Infiltration: $0.5 \mathrm{ACH}$. AC efficiency: 2.4COP Conversions US dollars based on rates as of June 62018 (1KWD=\$3.31)

Table 12- Savings due to changes in occupant cooling behaviour in villas 3 and 4

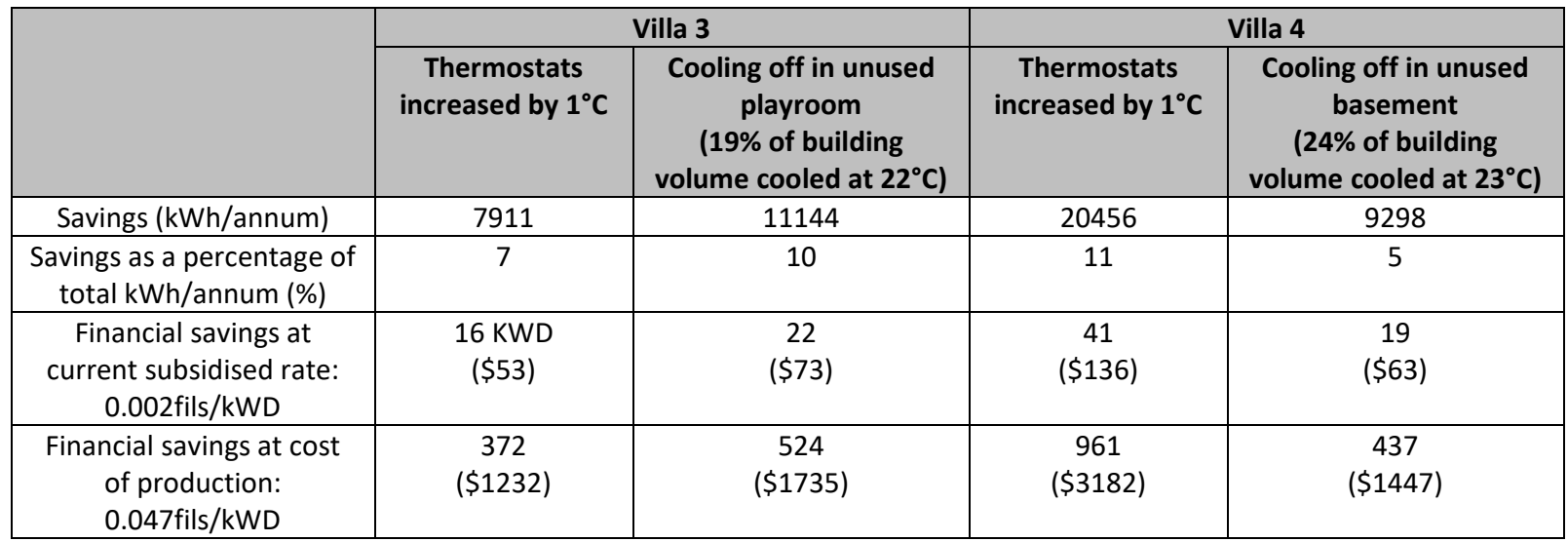




\section{Discussion}

This study examined the physical and social determinants of energy use in four case study villas in Kuwait. Key energy use drivers identified are discussed below:

- Occupant energy-use behaviours

The study indicated the impact of occupants in driving energy use, and in particular thermostat set points, an occupant controlled cooling behaviour. Simulation findings show that in newer villas, 3 and 4, where occupants used lower thermostat set points compared to those in older villas, a 1 degree rise in thermostat settings decreased annual energy use by $7 \%$ and $11 \%$ respectively. This is similar to findings from a recent quantitative survey of 250 Kuwaiti villas [5] undertaken by the authors of this paper, which found that for every degree rise in thermostat temperature settings, energy use decreases by about $10 \%$ (when all other factors remain constant). The effect of temperature set points on variations in energy use has also been reported by several researchers worldwide [5, 31, 33-36].

The monitoring study also provided insight into potential energy savings from thermostat adjustments during periods of extended summer travel. While homeowners of villas 2,3 , and 4 made no adjustments to their thermostats during periods of travel, those in villa 1 increased settings by $1^{\circ} \mathrm{C}$ during a one month vacation in July. This behaviour, together with no active appliance use, reduced measured energy use by about 35\% compared to the months of June and August. The wider impact of encouraging occupants to reasonably increase central $A C$ thermostats during periods of summer travel, on national peak demand and energy use is worth more detailed investigation in future studies. A number of other occupant cooling behaviours impacting energy use were also identified during the monitoring study such as the tendency among households to leave their central $A C$ switched on during months of the year when external temperatures are moderate (and windows are often left open), as well as a reactive approach towards AC maintenance. Such behaviours are likely being triggered by low electricity tariffs and slack payment requirements (bills paid on a random or annual basis) currently enforced in Kuwait.

- Household size and household income

The study provided insight on the potential impact of some socio-demographic factors on energy use including household size and household income. Villas with more occupants were found to have higher annual energy use intensities, higher energy use intensities during periods the AC was switched off, as well as higher plugs load intensities. This is in line with findings from the authors' larger quantitative survey of 250 villas [5] that found household size to be a significant predictor of energy use. Combining such findings, there appears to be some evidence that household size is an important determinant of energy use in Kuwait. With regards to household income however, no clear association with energy use was detected among the four villas. This is likely due to low electricity tariffs enabling lower income households to afford greater energy use, including larger villa sizes and the running costs associated with high appliance use. The percentage of income spent on energy in each villa was also found to be relatively low (between 0.6-1.4\%) compared with UK households that spent on average $4.4 \%$ of their total expenditure on energy [51]. 
- Building fabric and the impact of the MEW 1983 building code

The study found that fabric improvements associated with the MEW 1983 code have created more uniform internal temperatures especially during the hot summer and cold winter seasons. This is in line with findings from other researchers $[52,53]$, which note the influence of insulation on creating more stable indoor temperatures. The impact of fabric improvements on reducing energy use however could not be clearly determined in this study. When considering measured annual energy use $\left(\mathrm{kWh} / \mathrm{m}^{2}\right)$ no distinct reduction was found in newer post-code villas compared to older pre-code villas. Similarly, pre-code villa 1 did not significantly increase its measured energy use as external temperatures rose as was expected and observed in villa 2. When compared with simulation results, it seems there could be a potential difference in the actual AC and/or fabric performance of villa 1 relative to assumptions made. Further physical investigation and a larger sample of cases are thus required to better decipher the impact of fabric improvements on energy use.

- Villa size (built up area)

The study suggests that as a villa's buildings size (internal floor area) increases so does its annual energy use. This is in agreement with findings from previous studies that note building size as a key factor driving energy demand [5, 34, 54]. In Kuwait the effect of building size is likely to be accentuated as villas are largely centrally cooled, including many unused spaces, for 7-9 months of the year. In particular, simulation findings show that in the newer villas 3 and 4 , where a number of spaces were left unused, switching the cooling off in these spaces could in theory reduce energy consumption by $10 \%$ and $5 \%$ respectively.

\section{Conclusion}

This study has contributed to a better understanding of household energy consumption patterns closely related to building characteristics and occupant behaviours. Investigating how buildings perform in operation, over a period of one year, has shown that drivers of energy use in each villa are varied with both social and physical variables.

The study has a number of important implications for policy makers. First, it indicates the value of longitudinal studies that investigate both the physical and social aspects of buildings in their natural settings, including their energy use. Collecting and analysing longitudinal physical and social data is essential to better understand the complexity associated with household energy use. This, although costly, time consuming and faces the challenge of gaining access to private residences, enables a more comprehensive investigation of key factors affecting energy use. Governments and research institutions need to be prepared to invest and facilitate platforms for such studies. Second, the study demonstrates the value of grounding building models with empirical data to better predict energy use and inform policy. This is important as energy models are central to the policies of many governments worldwide. In this study, the empirical data gathered over 12 months allowed for the creation of a unique library file in Simergy, including specific templates of building materials, space cooling systems, lighting and occupant profiles more representative of villas examined in Kuwait. Such a file would also be useful for input into future simulations of Kuwaiti villas, in lieu of model default values not characteristic of this region. 


\section{Further work}

Although the study provided valuable empirical data and important insights, findings are indicative and further research is necessary to establish how representative the findings are of the national stock. The current study can act as a pilot demonstrating the key variables that any larger study would have to include. Furthermore, to better determine levels of building efficiency, detailed forensic examinations of building fabric and $A C$ system performance is required, which was beyond the scope of the current study.

\section{Acknowledgements}

This study was undertaken as part of a PhD research at the UCL Energy Institute. The authors are grateful to all the homeowners and occupants of the case study villas for their cooperation and time. The authors are also grateful to $U C L$ for the provision of monitoring devices in the longitudinal study.

\section{References}

[1] Ministry of Electricity and Water (MEW), Statistical year book 2018 - Electricity energy, https://www.mew.gov.kw/Files/AboutUs/Statistics/42/Ref713.pdf, 2018

[2] Alotaibi, S., Energy consumption in Kuwait: prospects and future approaches. Energy Policy, 39, pp.637-643, 2011.

[3] Wood, M., and Alsayegh, O., Impact of oil prices, economic diversification policies, and energy conservation programs on the electricity and water demands in Kuwait, Energy Policy, 66 144156, 2014

[4] Oxford Business Group, The Report - Kuwait 2015 www.oxfordbusinessgroup.com/country/Kuwait

[5] Jaffar, B., Oreszczyn, T., Raslan, R., Understanding energy demand in Kuwaiti villas: findings from a quantitative household survey, Energy and Buildings, 165 (2018) 379-389

[6] Hamilton, I., Summerfield, A., Lowe, R., Ruyssevelt, P., Elwell, C.A., Oreszczyn, T., 2013, Energy epidemiology: a new approach to end-use energy demand research. Building Research \& Information, 41(4), pp.482-497

[7] Oreszczyn, T., and Lowe, R., Challenges for energy and building research: objectives, methods and funding mechanisms. Building Research and Information, 38(1), pp.107-122, 2010

[8] Summerfield, A., Raslan, R., Lowe, R.J., and Oreszczyn, T., 2011, How useful are building energy models for policy? A UK Perspective. 12th Conference of International Building Performance Simulation Association: Proceedings of Buildings Simulation 2011. Sydney, 14-16 November, pp. 2477-2482

[9] Kavgic, M., Mavrogianni, A., Mumovic, D., Summerfield, A., Stevanovic, Z., Djurovic-Petrovic, M., A review of bottom-up building stock models for energy consumption in the residential sector. Building and Environment. 45, pp. 1683-1697, 2010

[10] Clarke, J., Johnstone, C., Kondratenko, I., Lever, M., McElroy, L., Prazeres, L., Strachan, P., McKenzie, P., and Peart, G., 2004. Using simulation to formulate domestic sector upgrading strategies for Scotland. Energy and Building. 36, pp.759-770

[11] Cali, D., Osterhage, T., Streblow, R., Muller, D., Energy performance gap in refurbished German dewellings: lessons learned from a field test. Energy and Buildings, 127, pp. 1149-1158, 2016

[12] Wilde, P., The gap between predicted and measured energy performance of buildings: $A$ framework for investigation. Automation in Construction. 41, pp.40-49, 2014 
[13] Menezes, A.C., Cripps, A., Bouchlaghem, D., and Buswell., R., Predicted vs. actual energy performance of non-domestic buildings: using post-occupancy evaluation data to reduce the performance gap. Applied Energy. 97, pp. 355-364, 2012

[14] Chiu, L.F., Lowe, R., Raslan, R., Altamirano-Medina, H., Wingfield, J., A socio-technical approach to post-occupancy evaluation: iteractive adaptability in domestic retrofit. Building Research \& Information, 42 (5) (2014) pp. 574-590

[15] Love, J., Cooper A., From social and technical to socio-technical: designing integrated research on domestic energy use. Indoor and Built Environment, 24 (7) (2015) 986-998

[16] Lowe, R., Chiu, L.F., and Oreszczyn, T., Socio-technical case study method in building performance evaluation. Building Research and Information, 46 (5) (2018) 469-484

[17] Kuwait Central Administration for Statistics, 2013, Income and Expenditure statistical report. Central Statistical Bureau. www.alqabas.com.kw/node/905575

[18] Kuwait MEW. Energy conservation program code of practice 1983. Kuwait City, Kuwait: Ministry of Energy and Water; 1983.

[19] Maheshwari, G.P., Al-Mulla, A., and Al-Hadban, Y., Energy management program for the state of Kuwait. International Journal of Energy Technology and Policy, 7 (1), pp. 95-112, 2009

[20] Ameer, B., and Krarti, M., Impact of subsidization on high energy performance designs for Kuwaiti residential buildings. Energy and Buildings, 116, pp.249-262, 2016

[21] Al-ajmi, F., and Hanby, V.I., 2008. Simulation of energy consumption for Kuwaiti domestic buildings. Energy and Buildings. 40, pp. 1101-1109

[22] Al-Ragom, F. 2003. Retrofitting residential buildings in hot and arid climates. Energy Conversion and Management, 44, pp. 2309-2319. 2003

[23] Al-Mumin, A., Khattab, O., Sridhar, G., Occupants' behaviour and activity patterns influencing the energy consumption in the Kuwaiti residences. Energy and Buildings, 35, pp.549-559, 2003

[24] Al-ajmi, F., and Loveday, D.L., 2010. Indoor thermal conditions and thermal comfort in airconditioned domestic buildings in the dry-desert climate of Kuwait. Building and Energy. 45, pp. 704-710

[25] Sadek, A.W., Fadala, S., and Al-Mutairi, N., 2006. Improving the design of residential buildings in Kuwait. Emirates Journal for Engineering Research. 11(2), pp.59-65

[26] Cerezo, C., Sokol, J., Reinhart, C., Al-Mumin, A., Three methods for characterizing building archetypes in urban energy simulation. A case study in Kuwait City. In: Proceedings of building simulation 2015; 2015. December 7-9, 2015, Hyderabad.

[27] Wolf, C.D., Cerezo, C., Murtadhawi, Z., Hajiah, A., Al-Mumin, A., Orchsendorf, J., Reinhart, C., Life cycle building impact of a Middle Eastern residential neighborhood. Energy.134, pp.336-348, 2017

[28] Assem, E.O., Al-Ragom, F., The effect of reinforced concrete frames on the thermal performance of residential villas in hot climates. International Journal of Energy Technology and Policy, 7, pp.46-62, 2009

[29] Krarti, M., and Hajiah, Analysis of impact of daylight time savings on energy use of buildings in Kuwait. Energy Policy, 39, pp. 2319-2329,2011

[30] Krarti, M., Evaluation of large scale building energy efficiency retrofit program in Kuwait. Renewable and Sustainable Energy Reviews .50, pp.1069-1080, 2015

[31] Steemers K., and Young Yun, G., Household energy consumption: a study of the role of occupants. Building Research and Information, 37 (5-6), pp.625-37, 2009

[32] Guerra Santin,O., Itard, L., and Visscher H., The effect of occupancy and building characteristics on energy use for space and water heating in Dutch residential stock. Energy and Building, 41 (2009) pp.1223-1232

[33] Abrahamse, W., Steg, L., How do socio-demographic and psychological factors relate to households direct and indirect energy use and savings? Journal of Economic Psychology , 30, pp.711-720, 2009 
[34] Huebner, G., Hamilton, I., Chalabi, Z, Shipworth, D., Oreszczyn, T., Explaining domestic energy consumption - the comparative contribution of building factors, socio-demographics, behaviours and attitudes. Applied Energy, (159) 2015 589-600

[35] Wei, S., Jones, R., Wilde, P., Driving factors for occupant-controlled space heating in residential buildings. Energy and Buildings, 70 (2014) 36-44

[36] Fabi, V., Andersonm R.K., Corgnati, S.P., Olesen, B.W., Occupants' window opening behaviour: A literature review of factors influencing occupant behaviour and models. Building and Environment, 58 (2012) 188-198

[37] Godoy-Shimizu, D., Palmer, J., Terry, N., What can we learn from the household electricity survey?. Buildings, 4 (2014) 737-761

[38] Hamilton, I., Summerfield A., Oreszczyn, T., Ruyssevelt, P., Using epidemiological methods in energy and buildings research to achieve carbon emissions targets. Energy and Buildings, 154, pp.188-197, 2017

[39] Saunders, M., Lewis, P., and Thornhill, A., 2009. Research methods for business students. $5^{\text {th }}$ ed. Harlow: Prentice Hall.

[40] HOBO 12 Temp/RH Data Logger (U12-012) User Manual, available at: http://www.onsetcomp.com/files/data-sheet/Onset\%20HOBO\%20U12\%20Data\%20Loggers.pdf

[41] Wall, R., and Crosbie, T., Potential for reducing electricity demand for lighting in households: An exploratory socio-technical study. Energy Policy, 37 pp.1021-1031, 2009

[42] Digital Alchemy, Simergy version 2.5.1: https://d-alchemy.com/

[43] Energyplus: https://energyplus.net/

[44] Custom weather file covering the period from 2015 to 2016 based on data retrieved from Kuwait International Airport Weather Station 405820

[45] Lomas, K.L and Eppel, H., Sensitivity analysis techniques for building thermal simulation programs. Energy and Buildings, 19, pp.21-44. 1992

[46] Raftery, P., Keane M., and O'Donnell J., Calibrating whole building energy models: An evidencebased methodology. Energy and Buildings. 43, pp. 2356-2364, 2011.

[47] Coakley D., Raftery P., Keane, M., A review of methods to march building energy simulation models to measured data. Renewable and Sustainable Energy Reviews, 37, pp123-141, 2014

[48] ASHRAE. Guideline 14-2002: measurement of energy and demand savings. Atlanta, GA 30329: American Society of Heating Refrigerating and Air-Conditioning Engineers, 2002

[49] EVO. International Performance measurement and verification protocol, volume 1, 2007. Efficiency Valuation Organization, Washington, DC, https://evo-world.org/en/products-servicesmainmenu-en/protocols/ipmvp.

[50] US DOE. M\&V guidelines: measurement and verification for federal energy projects version 3.0, US Department of Energy, 2008

[51] Ofgem,Energy spend as a percentage of total household expenditure, 2017, https://www.ofgem.gov.uk/data-portal/energy-spend-percentage-total-household-expenditureuk

[52] Fang, Z., Li, N., Li, B., Luo, G., Huang, Y., The effect of building envelope insulation on cooling energy consumption in summer. Energy and Buildings, 77 (2014) 197-205

[53] Al-Homoud, M., Performance characteristics and practical applications of common building thermal insulation materials. Building and Environment, 40 (2005) 353-366

[54] Kelly, S., Do homes that are more energy efficient consume less energy? A structural equation model of the English residential sector. Energy, 36 (9), pp.5610-5620, 2011 